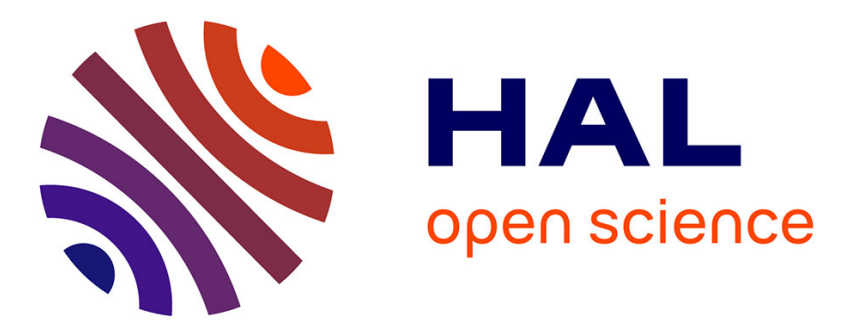

\title{
Doing More with Less: Innovation Input and Output in Family Firms
}

Patricio Duran, Nadine Kammerlander, Marc van Essen, Thomas Zellweger

\section{To cite this version:}

Patricio Duran, Nadine Kammerlander, Marc van Essen, Thomas Zellweger. Doing More with Less : Innovation Input and Output in Family Firms. Academy of Management Journal, 2016, 59 (4), 1224-1264 p. hal-02276703

\section{HAL Id: hal-02276703 https://hal.science/hal-02276703}

Submitted on 3 Sep 2019

HAL is a multi-disciplinary open access archive for the deposit and dissemination of scientific research documents, whether they are published or not. The documents may come from teaching and research institutions in France or abroad, or from public or private research centers.
L'archive ouverte pluridisciplinaire HAL, est destinée au dépôt et à la diffusion de documents scientifiques de niveau recherche, publiés ou non, émanant des établissements d'enseignement et de recherche français ou étrangers, des laboratoires publics ou privés. 


\title{
DOING MORE WITH LESS: INNOVATION INPUT AND OUTPUT IN FAMILY FIRMS
}

\author{
PATRICIO DURAN \\ Universidad Adolfo Ibáñez \\ NADINE KAMMERLANDER ${ }^{1}$ \\ WHU-Otto Beisheim School of Management \\ MARC VAN ESSEN \\ THOMAS ZELLWEGER \\ University of St. Gallen
}

\begin{abstract}
Family firms are often portrayed as an important yet conservative form of organization that is reluctant to invest in innovation; however, simultaneously, evidence has shown that family firms are flourishing and in fact constitute many of the world's most innovative firms. Our study contributes to disentangling this puzzling effect. We argue that family firms-owing to the family's high level of control over the firm, wealth concentration, and importance of nonfinancial goals-invest less in innovation but have an increased conversion rate of innovation input into output and, ultimately, a higher innovation output than nonfamily firms. Empirical evidence from a meta-analysis based on 108 primary studies from 42 countries supports our hypotheses. We further argue and empirically show that the observed effects are even stronger when the CEO of the family firm is a later-generation family member. However, when the CEO of the family firm is the firm's founder, innovation input is higher and, contrary to our initial expectations, innovation output is lower than that in other firms. We further show that the family firm-innovation input-output relationships depend on country-level factors; namely, the level of minority shareholder protection and the education level of the workforce in the country.
\end{abstract}

Family firms have often been portrayed as traditional firms that shy away from seeking new opportunities, that follow conservative strategies, and that ultimately are less innovative than other types of organizations (Economist, 2009). At the same time, however, evidence has revealed that more than half of the most innovative large European firms are controlled by family owners (http://www.forbes.com/ innovative-companies/list/). Moreover, the "German Mittelstand," which consists of a large number of rather resource-constrained family firms (Fiss \& Zajac,

We are grateful for the helpful comments of Linus Dahlander and the anonymous reviewers. Further, we acknowledge the valuable comments of Omar El Nayal, Melanie Richards, Andreas König, Michael Mol, Krishnan Nair, Reinhard Prügl, Steve Sauerwald, and Roxana Turturea, as well as participants of the Academy of Management 2014 Annual Meeting in Philadelphia and participants of the VHB TIE 2014 meeting in Munich, Germany on earlier versions of this manuscript.

${ }^{1}$ Corresponding author
2004), holds a large number of innovative "hidden champions" that also happen to be innovation leaders in their specific markets (Simon, 1996). Since roughly twothirds of all firms and one third of all publically listed firms worldwide can be considered family firms, and since those firms, in turn, contribute substantially to the majority of jobs and GDP on a global base (http://www. ffi.org/?page $=$ GlobalDataPoints), family firms can be considered an omnipresent and important organizational form of economies worldwide (La Porta, Lopezde-Silanes, \& Shleifer, 1999). As such, an advanced understanding of their innovation behavior is pressing.

Recent scholarly inquiries have started to illuminate the paradox of family firm innovation, but have reported inconclusive findings thus far. While some studies have provided empirical evidence for negative associations between family firms and innovation (Block, 2012; Chen \& Hsu, 2009; Chrisman \& Patel, 2012; Munari, Oriani, \& Sobrero, 2010), others have found positive effects (Gudmundson, Tower, \& Hartman, 2003; Kim, Kim, \& Lee, 2008; 
Llach \& Nordqvist, 2010). Moreover, from a theoretical perspective, previously applied theories fall short of comprehensively explaining the observed patterns of family firm innovation. For instance, prior applications of behavioral agency theory to family firm innovation (Chrisman \& Patel, 2012) have suggested that family firms typically underinvest in research and development (R\&D), but cannot explain the large number of innovative family firms, as mentioned above. The resourcebased view (Barney, 1991), by contrast, explains several resource orchestration advantages of family firms (Sirmon, Hitt, Ireland, \& Gilbert, 2011) but fails to predict family firms' low level of investment in innovation.

To disentangle these puzzling effects, we first propose that family firms are distinct from nonfamily firms with regard to the families' high levels of control over the firm, family wealth concentration, and the importance of nonfinancial goals in those firms. We then continue to theorize that those three idiosyncrasies lead to lower innovation input in family firms, but, at the same time, increase the conversion rate of innovation input into innovation output, ultimately resulting in higher levels of innovation output in family firms as compared to other forms of organizations. More specifically, the idiosyncrasies of family firms imply lower innovation input, defined as a firm's innovation-related financial investments (Ahuja, Lampert, \& Tandon, 2008), because such firms, relative to their nonfamily counterparts, face a limited availability of financial resources to be invested into innovation and because they hold a preference for investments characterized by low levels of uncertainty. Besides those influences of the family firm idiosyncrasies on the decision making and resource allocation within the organization, we also expect family firm idiosyncrasies to fundamentally render the conversion process of innovation input into output more efficient, as they imply the use of specific monitoring mechanisms and lead to the development of capabilities that are valuable for innovation. In particular, we emphasize resource orchestration (Sirmon et al., 2011), such as the deployment of valuable, firm-specific tacit knowledge and superior access to feedback from a trusted, external network. As a consequence of this efficient conversion process, family firms are characterized ultimately by high levels of innovation output, such as new product launches (Adams, Bessant, \& Phelps, 2006).

However, family firms are not a homogeneous group (Chua, Chrisman, Steier, \& Rau, 2012). In particular, the behavior of family firms with a family member as CEO has been shown to differ from that of family firms with an external CEO (Miller, Le Breton-Miller, Minichilli, Corbetta, \& Pittino, 2014), for instance, because of the different goals that those CEOs pursue. The notion that the CEO matters for family firm innovation resonates with innovation research that has long emphasized the important role of leadership (Alexiev, Jansen, Van den Bosch, \& Volberda, 2010; Crossan \& Apaydin, 2010; Mumford \& Licuanan, 2004; Vaccaro, Jansen, Van Den Bosch, \& Volberda, 2012): Firm leaders, and in particular CEOs (Jung, Chow, \& Wu, 2003), not only have substantial say in resource-allocation decisions (Hambrick \& Mason, 1984) but also monitor and direct the usage of those resources. CEOs encourage, select, and nurture innovation activities that emerge within the firm (Burgelman, 1991; West, Borrill, Dawson, Brodbeck, Shapiro, \& Haward, 2003), and they "create conditions for the subsequent implementation of innovation" (Crossan \& Apaydin, 2010: 1170). We thus study how the aforementioned relationships between family firms and innovation input-output change if the CEO is a family member. To do so, we distinguish between two types of CEOs who are family members, since prior research has revealed substantial differences among these two categories of leaders (Miller, Le Breton-Miller, \& Lester, 2011): (a) nonfounder family-member CEOs (henceforth, "family CEO”) and (b) founder CEOs. First, we argue that the abovementioned effects of family firm status on innovation input and output are strengthened if the CEO is a family CEO. In other words, family firms with a family CEO invest even less in innovation but have even higher innovation output owing to an increased conversion rate. Second, we argue that family firms with a founder CEO, mainly because of their idiosyncratic investment preferences, have higher innovation input. In line with the argumentation for family CEOs, we further expect that family firms with founder CEOs have higher innovation output.

To test our hypotheses, we conduct a metaanalysis based on 108 primary studies that focus on 42 countries for the period from 1981 to 2012. Metaanalytic techniques are particularly appropriate for this purpose because the body of existing data from a multitude of studies regarding family firm innovation is likely to provide deeper and more finegrained insights into our phenomenon compared to any single data set. Moreover, advanced metaanalytic techniques have been shown to be powerful tools for extending theory (Bergh et al., 2014; Combs, Ketchen, Crook, \& Roth, 2011). Specifically, 
we apply meta-analytic structural equation modeling (MASEM) to test the six abovementioned hypotheses. In a post hoc test based on meta-analytic regression analysis (MARA), we further reveal insights into how the hypothesized relationships between family firms and innovation input and output depend on country-level institutional factors.

Our study aims to make several contributions to the innovation literature. Research on innovation has long sought to understand the determinants of innovation in organizations (Damanpour, 1991; Schumpeter, 1934). While past research has studied an abundance of institution-, industry-, and firmlevel drivers of innovation (see Ahuja et al., 2008 for a summary), the role of a firm's governance constellation (Hoskisson, Hitt, Johnson, \& Grossman, 2002; Zhang, Zhang, \& Zhao, 2003), and in particular family control (Chrisman \& Patel, 2012; GómezMejía, Campbell, Martin, Hoskisson, Makri, \& Sirmon, 2014; Patel \& Chrisman, 2014), have been only scarcely addressed so far (De Massis, Frattini, \& Lichtenthaler, 2013). Incorporating the effect of family control into innovation studies is important for general management researchers, since the family firm is one of the most predominant organizational forms around the world (La Porta et al., 1999). We further advance the innovation literature not only by highlighting the importance of family control as a determinant of firm-level innovation, but also by pointing to the different effects that family control exerts on innovation input and output. Specifically, we identify family control as one of the scarcely understood determinants (Ahuja et al., 2008) that affect innovation input and output in opposite ways. Since we theorize and provide empirical evidence that family firms are particularly suited to convert innovation input into innovation output, our findings may also inform nonfamily firms striving to increase the efficiency of their innovation processes.

Moreover, our paper has strong implications for the growing body of literature on innovation in family firms. First, we disentangle innovation input and output to reconcile the conflicting views about family firm innovativeness. By building on three distinct characteristics of family firms-namely, family owners' high level of control over the firm, wealth concentration, and importance of nonfinancial goals-we show that family control undermines innovation input but that these very same attributes translate into superior innovation output. We thus provide a more comprehensive and nuanced picture of family firm innovation.
In addition, findings from our meta-analysis inform the scholarly debate on the heterogeneity of family- and founder-led firms (Chua et al., 2012). In particular, we contribute to the conversation regarding whether family firms should strive for increased management professionalization (GómezMejía, Larraza-Kintana, \& Makri, 2003; Stewart \& Hitt, 2012) and whether founder involvement is a blessing or a curse for important firm outcomes (Jayaraman, Khorana, Nelling, \& Covin, 2000; Miller et al., 2011). Specifically, we argue and empirically show that innovation output is even stronger when a family CEO is at the helm of the company. Interestingly, innovation output is lower when the founder is still active as the CEO of the company, even though such firms typically have higher investment in innovation.

Lastly, our findings also contribute to the understanding of innovation from an institution-based view (Peng, Sun, Pinkham, \& Chen, 2009; Peng, Wang, \& Jiang, 2008; Van Essen, Heugens, Otten, \& Van Oosterhout, 2012) since, in a post hoc test, we show that two important country-level factors-the level of minority shareholder protection and the education level of the workforce-moderate the hypothesized relationships between family firms and innovation input and output.

\section{THEORETICAL BACKGROUND}

\section{Innovation Input and Innovation Output}

Since Schumpeter's seminal work (1934), management research has focused on understanding the innovation behavior of organizations (for a review, see Ahuja et al., 2008). The constant renewal of products and processes is thereby associated with sustainable competitive advantages (D'Aveni, Dagnino, \& Smith, 2010; Garud \& Kumaraswamy, 1995; Garud, Tuertscher, \& Van de Ven, 2013) and, ultimately, superior financial performance (Andriopoulos \& Lewis, 2009; Calantone, Cavusgil, \& Zhao, 2002; Klomp \& Van Leeuwen, 2001). In particular, in today's hypercompetitive industries with shortened product life cycles, innovation has been considered one of the most important competitive advantages for firms (Cardinal, 2001; Dess \& Picken, 2000; Tushman \& O'Reilly, 1996).

When studying firm-level innovation, researchers have distinguished between two key conceptsinnovation input and innovation output (Adams et al., 2006). Innovation input is often defined and measured as a firm's financial investment that is 
dedicated toward the exploration and exploitation of new opportunities. In an often lengthy and complex innovation process (Cooper \& Kleinschmidt, 1987; Garud et al., 2013), innovation input is transformed into innovation output-in the form of, for instance, patented knowledge or newly developed products (Schmiedeberg, 2008), which can ultimately lead to superior firm performance (Bitard, Edquist, Hommen, \& Rickne, 2008; Kemp, Folkeringa, De Jong, \& Wubben, 2003).

While most researchers have assumed that a positive correlation exists between innovation input and innovation output (Acs \& Audretsch, 1988; Dosi, 1982), the "slope" of this relationship is likely to differ among organizations because of the complexity of innovation management (Klein \& Sorra, 1996; Mudambi \& Swift, 2011; Rothaermel \& Hess, 2007; Yayavaram \& Chen, 2015). In other words, organizations are likely to differ in their conversion ratethat is, in how efficiently they transform innovation input into innovation output.

To master the challenges associated with efficiently converting innovation input into innovation output, firms need to possess dynamic capabilities (Eisenhardt \& Martin, 2000; Teece, Pisano, \& Shuen, 1997; Zollo \& Winter, 2002); in particular, they need to excel in "resource orchestration" (Sirmon et al., 2011) because "resources alone are not likely to produce a sustainable competitive advantage [, ... yet those] resources must be managed appropriately to produce value" (Sirmon \& Hitt, 2003: 341). In other words, inefficient allocation and utilization of R\&D resources (Hitt, Hoskisson, Ireland, \& Harrison, 1991; Jensen, 2002)—caused, for instance, by organizational practices and routines that impede innovation (Henderson \& Clark, 1990), inadequate managerial incentive systems, or internal control system failures (Hitt et al., 1991)—can lead to a low conversion rate of innovation input into innovation output. For example, Gilbert (2005) illustrated that massive investments into new technologies do not necessarily result in superior products and services if, for instance, routines are not properly adapted.

Given the importance of innovation, it is not surprising that scholars have long sought to understand its drivers (e.g., see Becheikh, Landry, \& Amara, 2006 for a review). For instance, researchers have argued that an organization's level of innovation is substantially influenced not only by the size of the company, as proposed by Schumpeter (1934), but also by the firm's network (Chesbrough, 2003; Dahlander \& Gann, 2010), particularly its interactions with consumers (Von Hippel, 2005), and by the degree to which the firm is able to internalize and harvest external knowledge (absorptive capacity; Cohen \& Levinthal, 1990; Jansen, Van Den Bosch, \& Volberda, 2005; Zahra \& George, 2002). While scholarly interest in the impact of owners on firm innovation has recently increased (Hoskisson et al., 2002), the role of family firms remains largely ambiguous within this debate so far.

\section{Family Firms}

Although exact numbers for the prevalence of family firms vary, research has consistently shown that family firms dominate economies around the world (La Porta et al., 1999). In the United States, for instance, $40 \%$ of all publicly listed firms are family firms (Villalonga \& Amit, 2009). Family firms are organizations that are characterized by the existence of individuals, related by family ties, who exert substantial influence on the company, for example, via ownership stakes or important management positions held by family members (König, Kammerlander, \& Enders, 2013). ${ }^{1}$

While family firms are heterogeneous (Chua et al., 2012), for instance, with regard to the extent to which the family and business system overlap (Habbershon \& Williams, 1999), the literature seems to converge on the idea that family firms are characterized by the following three idiosyncrasies that render them distinct from other forms of organizations. First, family owners' substantial control over the firm-typically realized through voting rights-endows them with particular authority structures and incentives for monitoring managers and influencing processes within the organization (Carney, 2005; Gedajlovic \& Carney, 2010; Gedajlovic, Lubatkin, \& Schulze, 2004). Second, a large share of family firm owners' wealth is often invested into one firm, in an undiversified manner (Anderson, Mansi, \& Reeb, 2003). This wealth concentration increases owners' sensitivity to uncertainty and affects their firms' investment preferences, which thus differ from those

\footnotetext{
${ }^{1}$ Prior research has found that more than 30 definitions have been used in recent publications (O’Boyle, Pollack, \& Rutherford, 2012). In the remainder of this paper, we will follow recent research (Chrisman \& Patel, 2012; Gómez-Mejía et al., 2007; König et al., 2013) and assume that family firms are those characterized by high levels of family control, realized, for instance, through voting rights, managerial involvement, or family values and culture. In our empirical analysis, we control for different definitions of family firms that are used in the analyzed studies.
} 
of other forms of organizations (Anderson et al., 2003; Gómez-Mejía, Takács-Haynes, Núnez-Nickel, Jacobson, \& Moyano-Fuentes, 2007). Third and lastly, their high level of control over the firm and the often long shared history between the family and the firm leads to socioemotional endowments (Berrone, Cruz, Gómez-Mejía, \& Larraza-Kintana, 2010; Gómez-Mejía et al., 2007) and directs attention not only to financial but also nonfinancial goals, most importantly the continuation of family influence and the perseverance of long-established ties both within and outside the firm (Cruz, GómezMejía, \& Becerra, 2010; Zellweger, Kellermanns, Chrisman, \& Chua, 2012), which might ultimately affect organizational aspects, such as the firm's culture, the available routines and capabilities, and the firm's network. Because of these idiosyncrasies, family firms have been shown to differ from other firms in organizational behavior such as diversification (Gómez-Mejía, Makri, \& Larraza-Kintana, 2010), internationalization (Zahra, 2003), and investment policies, particularly with respect to investment time horizons (Anderson, Duru, \& Reeb, 2012). In the following, we will build on these three idiosyncrasies of family firms to deduce hypotheses on the family firm-innovation input and output relationships.

\section{DEVELOPMENT OF THE HYPOTHESES}

\section{Baseline Hypotheses: Family Firms and Innovation Input and Output}

Family firms and innovation input. Building on the abovementioned idiosyncrasies of family firms and the extant literature, we put forth two main reasons to expect that family firms, on average, have lower innovation input compared to other types of organizations. First, family firm owners' wealth is often concentrated ${ }^{2}$ in one or a few firms (Anderson et al., 2003). This wealth concentration renders family firm owners sensitive to the uncertainty inherent in their investments (Bianco, Bontempi, Golinelli, \& Parigi, 2013) and, consequently, incentivizes them to suspend investments in uncertain projects (cf. McGrath, 1997; Miller \& Folta, 2002).

\footnotetext{
${ }^{2}$ This concentration of wealth (as opposed to diversification) often stems from family firm owners' desire to exert substantial control over "their" firms. Since control over a firm typically requires a substantial amount of ownership stakes in a firm, family firm owners have to select one or few firms in which to invest the majority of their family's wealth.
}

Since innovation projects are a priori uncertain (Kline \& Rosenberg, 1986), for instance with regard to the timing and degree of technological and market success, family firm owners are expected to be unwilling to invest a substantial amount of resources into innovation. Instead, family firms tend to prefer investments in less uncertain assets, such as buildings and production machineries (Anderson et al., 2012), which render cash flows more predictable and allow for more stability-for instance, in dividend payments-relative to innovation projects (Miller et al., 2011).

Second, investment in innovation in family firms is often limited by family firm owners' socioemotional endowments and particularly by their nonfinancial goal to maintain their level of control over the firm (Gómez-Mejía et al., 2014; Sharma, Chrisman, \& Gersick, 2012). ${ }^{3}$ Depending on the industry and country, firms' average level of investment in innovation can exceed $10 \%$ of firm revenues (European Commission, 2013); therefore, innovation input that matches or exceeds the average input in the particular industry and country often cannot be financed internally, requiring external capital. Family firms, however, are known to be unwilling to increase their debt level or to raise money from the stock market (Mishra \& McConaughy, 1999). The underlying reason for such unwillingness is that family firm owners are reluctant to relinquish control over the firm-for instance, to external investorssince this would put their socioemotional wealth at risk (Gómez-Mejía et al., 2007). Consequently, their focus on the nonfinancial goal to maintain control renders family firms' innovation input limited per se (König et al., 2013).

On the basis of this discussion, we propose that while their relative independence from short-termoriented markets (Graham, Harvey, \& Rajgopal, 2005; Zellweger, 2007) would in principle allow family firms to take a long-term perspective and to make substantial investments in innovation, family firm owners' sensitivity to uncertainty and their nonfinancial desire to maintain control over the firm

\footnotetext{
${ }^{3}$ We do not expect any overall effect of family owners' goal to maintain relationships on innovation input. Such a nonfinancial goal might affect the distribution of innovation input to either exploratory (I_explore) or exploitative projects (I_exploit), but there is no reason to expect a significant effect on the amount of innovation input (I_total), which constitutes the sum of I_explore and I_exploit (see also discussion in König et al., 2013: 430-431).
} 
prevents them from doing so. Moreover, their unique power position allows family owners to readily enforce such investment preferences within the firm. Thus, we propose:

\section{Hypothesis 1a. Family firms have lower in- novation input compared to nonfamily firms.}

Family firms and innovation output. Family firm owners' sensitivity to uncertainty and their reluctance to relinquish control not only affect their firms' innovation input, but are also likely to determine their firms' orchestration of resources (Carnes \& Ireland, 2013) and thus how family firms convert innovation input into output, and, ultimately, their level of innovation output. We posit that family firms are particularly suited to efficiently converting innovation input into output. In other words, we expect that the lower innovation input in family firms does not transform into lower innovation output, for the following reasons.

At the outset, we suggest that family firm owners, owing to their high level of control, their wealth concentration, and their reluctance to relinquish control, are particularly willing and able to monitor the innovation process (cf. Fama \& Jensen, 1983). As the innovation literature has revealed, one major source of inefficiency during the innovation process stems from managerial activities that are not beneficial to the outcome of the innovation process (Roberts \& Fusfeld, 1981). For instance, managers can support their pet projects (Nohria \& Gulati, 1996) while denying support for other, more promising projects; political turmoil among middle managers can delay the implementation of innovation projects (Kanter, 1983; Shane, Venkataraman, \& MacMillan, 1995); and lavish use of the granted resources can introduce substantial inefficiencies into the process (Mudambi \& Swift, 2011). Such inefficiencies are commonly facilitated by the limited amount of information that (nonfamily) firm owners possess about the promise of specific innovation projects and their inability to closely monitor and influence the innovation process (Simester \& Zhang, 2010). Because of their high level of control, family firms are well suited to overcoming these issues and ensuring efficient transformation of innovation input into output, since family owners have superior power to implicitly and explicitly monitor managers (Uhlaner, 2013) and can act as "sophisticated investors" (Bushee, 1998). Moreover, their desire to avoid uncertainty and their reluctance to take on external money further motivates family firms to ensure an efficient or "parsimonious" (Carney, 2005) conversion of innovation input into innovation output.

In addition, we propose that the family owners' high level of control and their attention to nonfinancial goals lead to the development of specific resources and capabilities that foster the innovation process. Family firms have been shown to pursue nonfinancial goals such as creating and maintaining trust-based, long-term relationships with both firminternal and external stakeholders (Berrone, Cruz, \& Gómez-Mejía, 2012). We argue that pursuing such nonfinancial goals, over time, goes along with the development of a firm-level network, firm-internal human capital, and routines that are beneficial for the conversion of innovation input into output. Specifically, we posit that family firms benefit from privileged network access that fosters their innovation processes. An abundant body of innovation literature has emphasized the role of a firm's network within the innovation process since "networks can provide access to knowledge and resources that are not readily available via market exchanges" (Rothaermel \& Hess, 2007: 901). More specifically, network partners can propose novel and interesting ideas (Gassmann, Enkel, \& Chesbrough, 2010); they can provide valuable feedback throughout the innovation process (Garud et al., 2013; Tyre \& Von Hippel, 1997), for instance, through early and frequent interaction in the development and testing of prototypes (Thomke, 2003); and they can support the marketing of newly developed products (Schreier \& Prügl, 2008). ${ }^{4}$ We posit that family firms have privileged network access, as family firm owners' nonfinancial goals direct the attention of family firms to building up and maintaining long-term and trustbased relationships with external stakeholders such as suppliers (Berrone et al., 2012; Berrone et al., 2010), particularly those that are also family firms (Lester \& Cannella, 2006), and loyal customers (Miller \& Le Breton-Miller, 2005). Given the longterm, trust-based nature of those ties (Pearson, Carr, \& Shaw, 2008), family firms are particularly likely to receive valuable support from their network partners (cf. Phelps, 2010), and are also likely to pay attention

\footnotetext{
${ }^{4}$ In other words, while there is still a vivid debate in the innovation literature on the nuanced effects of, for instance, network closure (Rost, 2011), diversity, and density (Phelps, 2010) on firm innovation, we can conclude that access to valuable resources from network partners can foster the innovation process because innovation processes are "relational as they involve a diverse set of social actors” (Garud et al., 2013: 776).
} 
to, and ultimately implement, the suggestions of those selected and trusted sources (cf. Piezunka \& Dahlander, 2015). In summary, their focus on ties to external stakeholders, above and beyond economic (short-term) transactions, embeds family firms in a trust-based network (Uzzi, 1997) and endows them with a superior ability to leverage external networks, which has been labeled a manifestation of dynamic capabilities (Eisenhardt \& Martin, 2000; Teece et al., 1997).

We further argue that the focus of family firm owners on nonfinancial goals leads to particularly high levels of human capital and beneficial intraorganizational processes and systems that will further support the innovation process in family firms. ${ }^{5}$ Family firm owners' goal to build up long-term, trustbased relationships also extends to firm-internal stakeholders (Miller \& Le Breton-Miller, 2005). Indeed, the community of family firm employees has been labeled a "pseudo-family" (König et al., 2013; Tan \& Fock, 2001), and tenures appear to be substantially longer in family firms compared to in nonfamily firms (Lansberg, 1999), leading to high levels of experience and deep task-, product-, and market-specific knowledge among the employees. This attribute of family firms is likely to play an important role in the innovation process, since "a firm's innovative performance is at least partially a function of the value of its human capital" (Rothaermel \& Hess, 2007: 899). High levels of human capital within a firm are beneficial within the innovation process (Acs \& Audretsch, 1988; Hadjimanolis, 2000), because the interaction of experienced and skilled employees leads to the accumulation of implicit or tacit knowledge (Almeida, Song, \& Grant, 2002; Henderson \& Cockburn, 1994; Kogut \& Zander, 1992; Leonard-Barton, 1992), which, in turn, fosters the development of new technologies (Dosi, 1982). We thus expect that the high level of commitment (Donnelley, 1964) and tacit knowledge among employees (Sirmon \& Hitt, 2003) in family firms will foster the transfer of valuable ideas across hierarchies and departments (Bammens, Notelaers, \& Van Gils, 2015) and thereby support the resource orchestration within the firm. In other words, the monitoring and the nonfinancial goals of family firms are likely to

\footnotetext{
${ }^{5}$ While a focus on internal human capital and training of extant staff can be an impediment in times of radical shifts (e.g., Gilbert, 2005; König et al., 2013), well-trained, experienced, and motivated employees positively affect a firm's innovativeness in the more common period of evolutionary progress characterized by incremental innovation.
}

entail high levels of tacit knowledge among employees and the existence of systems and processes that are capable of efficiently transforming innovation input into innovation output over time. Thus, we propose the following hypothesis:

Hypothesis 1b. Family firms have higher innovation output compared to nonfamily firms.

\section{Leadership Variables and the Family Firm-Innovation Relationship}

In the following, we will illuminate how two important leadership variables affect the aforementioned hypotheses. Prior research on innovation has increasingly highlighted the important role of firm leadership (for a summary, see Rosing, Frese, \& Bausch, 2011), and particularly CEOs (Jung et al., 2003), in the innovation process. As Crossan and Apaydin (2010) summarized, firm leaders, and particularly CEOs, can influence firm innovation in various ways: First, CEOs shape the firm's strategy and resource allocation process (and hence its innovation input). While owners provide important guidelines on how to invest the firm's resources, CEOs still possess substantial leeway in adapting resource-allocation decisions in line with their own values and beliefs (Finkelstein \& Hambrick, 1990; Hambrick \& Mason, 1984). Second, CEOs shape the innovation process and, consequently, innovation output by selecting and promoting middle managers as "innovation champions" and by guiding them in their implementation of innovation projects (Jansen, Vera, \& Crossan, 2009). Third, CEOs play an important role in setting up structures and systems that allow for organizational learning and effective knowledge management (Crossan, Lane, \& White, 1999; Damanpour, 1991). Lastly, CEOs can foster an innovative culture (Pinto \& Prescott, 1988).

The notion that the CEO matters is also at the core of the family business literature. This literature has highlighted the particularities of family firms with either a (nonfounder) family member as the CEO (e.g., Gómez-Mejía et al., 2003; Miller et al., 2011) or the founder as the CEO (Le Breton-Miller \& Miller, 2008). Accordingly, family CEOs and founder CEOs are considered two distinct types of leaders (Villalonga \& Amit, 2006). Chua, Chrisman, and Chang (2004) also called for a distinction between family and founder CEOs in family firms by suggesting that family firms are progressively imbued with family-specific attributes-most often through the gradual involvement of later-generation family 
members in the leadership position of the firm (Holland \& Oliver, 1992). ${ }^{6} \mathrm{~A}$ distinction between family and founder CEOs is further warranted because of founders' specific risk preferences and pursued goals (Fahlenbrach, 2009), which we will explore in more detail below.

Family CEOs and innovation input. We first argue that the proposed negative relationship between family firms and innovation input, which we theorized in Hypothesis 1a, becomes even stronger when the CEO is a family member. In other words, we expect that family firms invest even less in innovation when a family CEO is at the helm of the company, due to the following reasons.

First, in family firms with a family CEO, firm decisions made by the CEO in general, and innovation investments in particular, mirror the family firm owners' investment preferences. The underlying rationale of this is that the family CEO typically has his or her personal wealth concentrated in the firm, possesses control through ownership rights, and pursues nonfinancial goals such as maintaining ownership control within the hands of the family (Chrisman, Chua, \& Litz, 2004). As such, a family CEO is likely to share the family firm owners' reluctance to invest in innovation (see the arguments provided for Hypothesis 1a). The investment preferences of CEOs who are not family members, however, are likely to deviate from the investment preferences of the family firm owners (Singla, Veliyath, \& George, 2013), because their wealth is typically not concentrated in the firm, they do not possess substantial ownership rights, and they do not follow the same nonfinancial goals as family firm owners do. Hence, a family-external CEO might utilize his or her managerial discretion (Finkelstein \& Hambrick, 1990) to pursue higher investment in innovation compared to a family CEO, for instance, to push for more strategic conformity (Miller, Le Breton-Miller, \& Lester, 2013) or to stand out in the executive labor market (Gerstner, König, Enders, \& Hambrick, 2013).

Second, we argued above that family firm owners refuse to make substantial investments in innovation because they are reluctant to cede control over their firm, which would put their socioemotional wealth at risk. We suggest that this effect is even stronger when the CEO is a family member, because ceding control-for instance, to external investors-would not only limit his or her shareholder voting power (as

\footnotetext{
${ }^{6}$ While family CEOs are often descendants of the firm's founder, they may also be unrelated to the founder if the family has acquired but not founded the firm under control.
}

an owner) but also restrict the latitude of his or her managerial actions and decisions (as a manager). As such, we expect that family CEOs are even less willing to dedicate substantial amounts of financial resources to innovation compared to firms without a family CEO. Thus, we propose the following hypothesis:

Hypothesis 2a. Family firms with a family CEO have even lower innovation input than those without a family CEO.

Founder CEO and innovation input. Founder CEOs take on a special role within the group of CEOs; thus, they differ from family CEOs described above. More specifically, founder CEOs typically possess investment preferences that differ from those outlined in our argumentation for Hypothesis 1a, for the following two reasons. First, founder CEOs are less sensitive to risk and uncertainty. The reason for this is that founding a business requires tolerance of risk and uncertainty, since entrepreneurial activities are risky by nature (Caliendo, Fossen, \& Kritikos, 2009). Hence, self-selection implies that founders are typically at ease with making uncertain investments (Jayaraman et al., 2000; McClelland, 1965), which renders them less reluctant to invest in innovation. As risk preferences are not inherited (Bertrand, Johnson, Samphantharak, \& Schoar, 2008), this effect is likely to hold only for founder CEOs, but not for later-generation family CEOs (Cucculelli, Le Breton-Miller, \& Miller, 2014).

Second, founder CEOs also differ in terms of goals (Cannella, Jones, \& Withers, 2015; Miller et al., 2011). While, as outlined above, one of family owners' primary goals is to maintain control over the firm (Gómez-Mejía et al., 2007), for a founder CEO, this goal is likely to be superposed by his or her strong desire for growth (Miller et al., 2011). As innovation is one of the most promising ways to achieve growth, founder CEOs are thus expected to be highly willing to invest in innovation.

Given that founder CEOs, who typically possess major shares in their firm, have the power to make investment decisions according to their own investment preferences, we propose the following hypothesis:

Hypothesis 3a. Family firms with a founder CEO have higher innovation input than those without a founder CEO.

Family or founder CEOs and innovation output. Whereas the diverging risk preferences and goals of family CEOs and founder CEOs lead to substantial heterogeneity in innovation input among family firms, we do not expect to find such differences when 
investigating innovation output. Instead, we expect that the presence of either a family CEO or a founder CEO in a family firm results in even higher innovation output than the presence of an external CEO does. As outlined above, the innovation process that converts innovation input into output is less influenced by resource allocation preferences (as is the case for innovation input), and is more influenced by the firm's resource orchestration, in particular its monitoring efforts, and its exploitation of firm-external network ties, human capital, and routines.

In our baseline hypothesis (Hypothesis 1b), we argued that owing to their high level of control and their wealth concentration, family firm owners are motivated and able to act as "sophisticated" owners who monitor innovation activities in a powerful way and who thereby ensure efficient conversion of innovation input into innovation output. If the CEO is a family or founder CEO, his or her willingness and ability to efficiently monitor the innovation process will be even higher (Anderson \& Reeb, 2003). Previous research in the context of technological innovation in the pharmaceutical industry (Cardinal, 2001) has shown that such increased control on not only the firm level but also the project level leads to a more efficacious and less wasteful innovation process. This line of argumentation is valid for both family and founder CEOs, since both types of CEOs are characterized by high levels of personal control and wealth concentration and are thus willing and able to engage in an efficient monitoring process. Hence, we argue that the alignment of interests between owners and managers in the case of founder or family CEOs amplifies the positive relationship between family firms and innovation output.

Another core element of our baseline hypothesis is that access to long-established, trust-based relationships with customers, suppliers, and other (family) firms endows family firms with valuable complementary assets and knowledge that are beneficial for the efficient conversion of innovation input into output. Family firms with family or founder CEOs might be even more able to exploit such relationships. First, family and founder CEOs closely identify with "their" firm (Berrone et al., 2012), and are likely to stick with their firm, even when the firm is in trouble $^{7}$ (Lansberg, 1999). Such characteristics may

\footnotetext{
${ }^{7}$ In addition to their often-observed high levels of commitment to the firm, family CEOs and founder CEOs have less employment risks owing to their long-term contracts that are typically not tied to performance goals (Gómez-Mejía, Núñez-Nickel, Gutierrez, 2001).
}

enhance their partners' trust in the CEO's benevolence and long-term view and may render partners more likely to openly provide candid and useful feedback to the family firm. As trust is an important antecedent for harnessing a firm's network in the innovation process (Phelps, 2010), we argue that firms with a family or founder CEO are particularly able to exploit external knowledge to create innovation output. Both founder and family CEOs might be considered trusted partners because of their high levels of attachment to the firm (Wasserman, 2003; Zellweger et al., 2012).

Moreover, we argued above that family firms benefit from the accumulation of human capital within the firm and the creation of efficient routines when converting innovation input into innovation output. When the CEO is a family or founder CEO, his or her individual-level human capital might be beneficial for harvesting such advantageous firmlevel human capital during the innovation process and, as such, for the family firm's resource orchestration. In particular, family and founder CEOs are endowed with superior knowledge, particularly tacit knowledge (Nonaka \& Takeuchi, 1995; Polanyi, 1973; Von Krogh, Ichijo, \& Nonaka, 2000), about their firm's members, routines, and stakeholders, which external CEOs possess to a lesser degree. For instance, family and founder CEOs are likely to possess superior knowledge about which employees to select as innovation champions and about which task to delegate to which group within the organization. Such tacit knowledge is likely to foster superior conversion of innovation input into innovation output for several reasons. First, the CEO's deep, implicit knowledge about the family firm's processes and systems and about the finegrained (individual-, group-, and organizationallevel) capabilities that are available across the firm (Le Breton-Miller \& Miller, 2015) will allow for superior orchestration of resources and thus superior conversion of innovation input into output. Given that knowledge management is a challenging task that is at the core of the innovation process (Madhavan \& Grover, 1998; Subramaniam \& Youndt, 2005), such individual-level tacit knowledge of family or founder CEOs will lead to superior innovation output (Carnes \& Ireland, 2013; Sirmon et al., 2011). Second, because of their profound understanding of their firm's culture and their personal, strong affiliation with the firm, family and founder CEOs are uniquely positioned to "make innovation happen via a strong vision" (Adams et al., 2006: 31, referring to Pinto \& Prescott, 1988). 
Both family and founder CEOs possess such valuable individual-level human capital, particularly knowledge about the internal affairs of their firm. Family CEOs are expected to possess this knowledge because they are a "familiar and motivated pool of talent, thanks in part to the more effective transmission of knowledge [compared to family-external CEOs] about the business from a founder to his or her offspring” (Miller et al., 2014: 549), with the transfer of knowledge often starting as early as the future CEO's childhood (Cabrera-Suarez, Saa-Perez, \& GarciaAlmeida, 2001; Le Breton-Miller \& Miller, 2015; Naldi, Cennamo, Corbetta, \& Gómez-Mejía, 2013). Founder CEOs as "focal points" (Nelson, 2003) of their organizations possess this kind of knowledge because they have known the business since its inception. Indeed, prior research has often emphasized the unique human capital of founder CEOs (Colombo \& Grilli, 2005; Gimmon \& Levie, 2010; Kaplan, Sensoy, \& Strömberg, 2009; Zingales, 2000). We thus propose the following hypotheses:

Hypothesis 2b. Family firms with a family CEO have higher innovation output than those without a family CEO.

Hypothesis 3b. Family firms with a founder CEO have higher innovation output than those without a founder CEO.

Table 1 provides an overview of the proposed relationships, as well as the underlying rationales.

\section{METHODS}

\section{Sample and Coding}

To test our hypotheses, we conducted a metaanalytic study following the established guidelines put forth in management and economics research (Buckley, Devinney, \& Tang, 2013; Kepes, McDaniel, Brannick, \& Banks, 2013; Stanley et al., 2013). We used five complementary search strategies to identify the population of studies that quantitatively compared the innovation behavior of family firms with that of nonfamily firms (Heugens, Van Essen, \& Van Oosterhout, 2009). First, we consulted several review and meta-analytic articles, such as a narrative review on innovation in family firms (e.g., De Massis et al., 2013) and a published meta-analysis on family firms and firm performance (O'Boyle, Pollack, \& Rutherford, 2012). Second, we searched five major electronic databases (ABI/INFORM Global, EconLit, Google Scholar, JSTOR, and SSRN) by using the following search terms: "blockholder," "families," "family business," "family control," "family firm," "family ownership," "founder," "founding family," "lone founder," and "ownership." We combined these key terms with the following terms related to innovation variables: "innovation," "patent," "new product introduction," and "R\&D." Third, we conducted a manual search of journals in the disciplines of economics, finance, and management that periodically publish articles related to family firms. Fourth, after collecting an initial set of studies, we used a "snowballing" technique (Von Hippel, Franke, \& Prügl, 2009) that involved backwardtracking all the references reported in the articles and tracing forward all articles that cite the original articles by using Google Scholar. Fifth, we directly contacted authors of one or several papers relevant to this topic who did not report information on effect sizes or whose studies we could not retrieve. We asked these authors for a correlation table, regression output, and additional empirical studies. After conducting these five steps and removing any manuscripts that used data that were identical to those of other studies, we arrived at a final sample of 108 primary studies, which consisted of 71 published manuscripts (i.e., journal articles) and 37 unpublished manuscripts (comprising 32 working papers and five theses) covering 42 countries in the 1981-2012 period (see Appendix A for an overview of the 108 primary studies). This systematic search process, which aimed to minimize the odds of "missing a useful paper that lies outside one's regular purview" (White, 1994: 44), followed recent best practices for sampling in meta-analyses (Buckley et al., 2013; Stanley et al., 2013).

Subsequently, we read all the articles and developed a coding protocol (Lipsey \& Wilson, 2001) for extracting data related to all the relevant variables, including effect sizes, sample sizes, and leadership variables. While one author extracted and coded all the data, another author coded a subsample of 68 randomly selected effect sizes to assess the degree of agreement in extracting information from primary studies (Stanley et al., 2013). We obtained a high inter-rater agreement of .98 (Cohen's $\kappa$ coefficient; Cohen, 1960).

\section{MASEM Procedure}

We used MASEM (Bergh et al., 2014; Cheung \& Chan, 2005; Viswesvaran \& Ones, 1995) to test our hypotheses. The MASEM procedure combines the techniques of structural equation modeling with those of meta-analysis (Cheung \& Chan, 2005). The 
TABLE 1

Summary of Predictions

\begin{tabular}{|c|c|c|}
\hline & Innovation input & Innovation output \\
\hline Family firm & $\begin{array}{l}\text { Hypothesis 1a: Lower innovation input in family firms: } \\
\text { - Wealth concentration leads to a reluctance to make } \\
\text { uncertain investments. Innovation is a particularly } \\
\text { uncertain investment. } \\
\text { - Nonfinancial goals, particularly the desire to maintain } \\
\text { control, lead to a reluctance to take on external money. } \\
\text { Investments that match or even exceed industry-average } \\
\text { R\&D expenses often require external funding. } \\
\text { - A high level of control allows the owners' (low innovation } \\
\text { input) investment preferences to be followed. }\end{array}$ & $\begin{array}{l}\text { Hypothesis 1b: Higher innovation output in family firms: } \\
\text { - A high level of control leads to a better ability to monitor the } \\
\text { innovation process and thus avoid "waste." } \\
\text { - The desire to avoid uncertainty (stemming from wealth } \\
\text { concentration) and the desire to maintain control (i.e., } \\
\text { a nonfinancial goal) leads to a high willingness to monitor } \\
\text { the innovation process. } \\
\text { - The pursuit of nonfinancial goals over time also leads to } \\
\text { privileged access to networks and to unique firm-internal } \\
\text { tacit knowledge and routines, which have been shown to } \\
\text { be beneficial throughout the innovation process. }\end{array}$ \\
\hline Family CEO & $\begin{array}{l}\text { Hypothesis 2a: Even lower innovation input when the CEO is } \\
\text { a family CEO: } \\
\text { - The superior alignment of owners' and family CEO's } \\
\text { preferences (high level of control of the family CEO) leads } \\
\text { to better implementation of family owners' investment } \\
\text { preferences. } \\
\text { - Family CEOs' own wealth concentration and their } \\
\text { nonfinancial goal to retain control (incl. managerial } \\
\text { power) is at stake if external funding is used to finance } \\
\text { innovation projects. }\end{array}$ & $\begin{array}{l}\text { Hypothesis 2b: Even higher innovation output when the CEO } \\
\text { is a family CEO: } \\
\text { - Family CEOs have increased power (due to high level of } \\
\text { control) and motivation (due to wealth concentration) to } \\
\text { monitor the innovation process owing to an overlap of } \\
\text { ownership and management. } \\
\text { - Family CEOs have more privileged network access because } \\
\text { of increased trust, which will be beneficial throughout the } \\
\text { innovation process (effect of nonfinancial goals, as argued } \\
\text { in Hypothesis 1b, strengthened). } \\
\text { - Family CEOs have individual-level tacit knowledge (given } \\
\text { the inter-generational knowledge transfer), which helps } \\
\text { them to efficiently orchestrate the resources within the firm } \\
\text { during the innovation process (effect of nonfinancial goals, } \\
\text { as argued in Hypothesis 1b, strengthened). }\end{array}$ \\
\hline Founder CEO & $\begin{array}{l}\text { Hypothesis 3a: Higher innovation input when the CEO is } \\
\text { a founder CEO: } \\
\text { - Founder CEOs, due to a self-selection process, are more } \\
\text { risk-seeking and less sensitive to uncertainty (thereby } \\
\text { alleviating the effect of wealth concentration, as argued for } \\
\text { Hypothesis 1a). Consequently, they are less reluctant to } \\
\text { invest in innovation. } \\
\text { - Founder CEOs are particularly driven by goals to grow the } \\
\text { firm. Growth can be well facilitated by investment into } \\
\text { innovation. Moreover, concerns about nonfinancial goals } \\
\text { (as argued for Hypothesis 1a) are less important. }\end{array}$ & $\begin{array}{l}\text { Hypothesis 3b: Even higher innovation output when the CEO } \\
\text { is a founder CEO: } \\
\text { - Founder CEOs have increased power (due to high level of } \\
\text { control) and motivation (due to wealth concentration) to } \\
\text { monitor the innovation process owing to an overlap of } \\
\text { ownership and management. } \\
\text { - Founder CEOs have more privileged network access } \\
\text { because of increased trust, which will be beneficial } \\
\text { throughout the innovation process (effect of nonfinancial } \\
\text { goals, as argued in Hypothesis 1b, strengthened). } \\
\text { - Founder CEOs have individual-level tacit knowledge } \\
\text { (given their focal position within the firm), which helps } \\
\text { them to efficiently orchestrate resources within the firm } \\
\text { during the innovation process (effect of nonfinancial goals, } \\
\text { as argued in Hypothesis 1b, strengthened). }\end{array}$ \\
\hline
\end{tabular}

technique is ideal for testing our hypotheses because it allows us to test the relationships among family firms, innovation input, and innovation output in a single model. MASEM is more advantageous than more conventional meta-analytic techniques because the relationships under investigation do not need to have been tested in each primary study and because the technique avoids biased estimates when simultaneity effects may be involved and when the risk of collinearity among variables exists (Geyskens, Krishnan, Steenkamp, \& Cunha, 2009).
MASEM tests were conducted in a two-stage procedure (Carney, Gedajlovic, Heugens, Van Essen, \& Van Oosterhout, 2011). In the first stage, we used Hedges and Olkin-type meta-analysis (HOMA; Hedges \& Olkin, 1985) to compute the meta-analytic mean associations between all variables, based on Pearson product-moment correlations $(r)$. The outcome of this procedure was a meta-analytic correlation table (see Table 2). We used random-effects HOMA, which accounts for the potential heterogeneity of effect size distributions and is considered 
more conservative than fixed-effects HOMA (Kisamore \& Brannick, 2008; Raudenbush \& Bryk, 2002). In recent years, artifact-corrected meta-analytic methods (ACMA; Hunter \& Schmidt, 2004) have become increasingly popular (Heugens \& Lander, 2009). However, because most studies on family firms have been based on independently verifiable economic data rather than on self-reported psychometric data, randomeffects HOMA is the more appropriate choice for estimating mean effect sizes in our research setting (Kepes et al., 2013; Rosenthal, 1991). ${ }^{8}$

When multiple measurements of the focal effect were reported in one study (such as different definitions of a family firm), we included all of them in our analyses. Monte Carlo simulations showed that procedures using the complete set of measurements outperformed those representing each study by a single value in areas such as parameter significance testing and parameter estimation accuracy (Bijmolt \& Pieters, 2001). For accuracy reasons, we weighted the effect sizes by their inverse variance weight $(w)$ (Hedges \& Olkin, 1985). ${ }^{9}$ Next, we used these weights to compute the standard error of the mean effect size and its corresponding confidence interval. ${ }^{10}$

In the second stage, we treated the meta-analytic correlation matrix that was generated by the HOMA procedure as the observed correlation matrix and subjected it to regular maximum likelihood structural equation modeling routines to test the aforementioned hypotheses (Cheung \& Chan, 2005). To address sample size differences across the correlation coefficients that were included in our matrix, we based our analysis on the harmonic mean sample size (Landis, 2013). The harmonic mean is

\footnotetext{
${ }^{8}$ The results of robustness tests based on ACMA are similar to those of the Hedges and Olkin-type meta-analysis and support our findings. HOMA (bivariate as well as bivariate and partial) are shown in Appendices $B$ and $C$. ACMA results are available upon request from the authors.

${ }^{9} w$ is calculated as follows: $w_{i}=\frac{1}{s e_{i}^{2}+\hat{v}_{\theta}}$, where $s e$ is the standard error of the effect size and $\hat{V}_{\theta}$ is the variance component of the random effects. These variables are calculated as $\operatorname{se}\left(z_{r}\right)=\frac{1}{\sqrt{n-3}}$ and $\hat{v}_{\theta}=\frac{Q_{r}-k-1}{\sum w-\left(\frac{\sum w^{2}}{\sum w}\right)}$

${ }^{10}$ The meta-analytic mean is calculated as follows: $\overline{E S}=\frac{\sum(w \times E S)}{\sum w}$. Its standard error is calculated as $s e_{\overline{E S}}=$ $\sqrt{\frac{1}{\sum w}}$, and with its $95 \%$ confidence interval computed as Lower $=\overline{E S}-1.96\left(s_{\overline{E S}}\right)$, Upper $=\overline{E S}-1.96\left(s_{\overline{E S}}\right)$.
}

less sensitive to outliers than the arithmetic mean is; thus, it provides more correct and conservative $t$ values for model parameters (Geyskens, Steenkamp, \& Kumar, 2006). To test our hypotheses, we assessed the following: (1) the direct effect of family firm status on innovation input, (2) the effect of family firm status on innovation output, and (3) the effect of innovation input on innovation output. We thus tested the following system of simultaneous equations:

Innovation input $=\beta_{1}$ family firm status

$$
+\beta_{2} \text { firm size }+\varepsilon
$$

$$
\begin{aligned}
\text { Innovation output }= & \beta_{3} \text { family firm status } \\
& +\beta_{4} \text { firm size } \\
& +\beta_{5} \text { Innovation input }+\varepsilon
\end{aligned}
$$

The models also controlled for the influence of firm size (total assets, sales, or employees) because firm size is known to affect firms' strategic decisions (Beatty \& Zajac, 1994) in general, and innovation in particular (Schumpeter, 1934).

Innovation input. As innovation input, we considered those variables coded in the primary studies that relate to R\&D investment: (1) the ratio of a firm's total annual R\&D expenditures to total sales (cf. Munari et al., 2010), (2) the ratio of a firm's total annual R\&D expenditures to total assets (also referred to as R\&D intensity [Wu, Levitas, \& Priem, 2005]), (3) R\&D expenditures divided by the sum of R\&D expenditures and capital expenditures (Anderson et al., 2012), (4) the ratio of the number of R\&Dfocused employees to total employees (Sirmon, Arregle, Hitt, \& Webb, 2008), (5) the ratio of external expenses for R\&D to total sales (also referred to as external technology acquisition [Kotlar, De Massis, Frattini, Fang, \& Bianchi, 2013]), and (6) R\&D expenses divided by the firm's equity market value (Croci, Doukas, \& Gonenc, 2011). Appendix A provides an overview of the operationalization of the variables used in the primary studies.

Innovation output. We categorized a variable as an innovation output variable if it related to new product introduction and patent creation. In this category, we included variables such as the following: (1) the percentage of sales that consisted of new products or services introduced (Wu, 2008), (2) the number of patents granted to a firm (Tsao \& Lien, 2013), (3) the ratio of the number of patents granted to a firm to R\&D investment (Anderson, Duru, \& Reeb, 2009), (4) the number of patent citations (Hsieh, Yeh, \& Chen, 2010), (5) the ratio of the number of patent 
citations to R\&D investment (Anderson et al., 2009), and (6) whether the firm introduced innovation during a determined number of years (Laursen, Masciarelli, \& Prencipe, 2012).

Family firm. We consider firms that were classified as a "family firm" in the primary studies to be family firms for this meta-analysis. As the literature has not yet converged on a clear definition of what a family firm is (see e.g., Miller, Le Breton-Miller, Lester, \& Cannella, 2007; Villalonga \& Amit, 2006), the primary studies that were used for this metaanalysis relied on different criteria to distinguish family and nonfamily firms (see Appendix A for details). ${ }^{11}$ To take this heterogeneity into account, we created the following four mutually exclusive categories of family firm definitions, which account for all definitions applied in the respective primary study, and we used those study-level variables in the HOMA and MARA calculations: (1) firms with a substantial presence of family members in ownership by either voting or cash flow rights (Peng \& Jiang, 2010), (2) firms with a substantial presence of family members in top management positions (Miller et al., 2007), (3) firms with a family presence in ownership and management (Gómez-Mejía et al., 2014), and (4) firms with a family presence in ownership or management (Villalonga \& Amit, 2006).

To test Hypotheses $1 \mathrm{a}$ and $1 \mathrm{~b}$, we applied a dummy variable distinguishing between "family firms"-independent of the specific definition used by the primary studies-and nonfamily firms. To test Hypotheses 2a, 2b, 3a, and 3b, we disentangled family firms with a family CEO or a founder CEO based on the information on founder presence and the involved family generations presented in the primary studies.

\section{MARA Procedure}

The relationship between family firms and innovation input and output as reported in this metaanalytic study might be affected by the research design and model specification used in the primary studies and by institutional effects (Scott, 2001). To account for these effects, we applied MARA (Lipsey \& Wilson, 2001) as a post hoc test. In our MARA analyses, the dependent variable is the effect size for the relationship between family firm and innovation

\footnotetext{
${ }^{11}$ Most of the primary studies used dummy variables to differentiate between family firms and nonfamily firms, and only a few studies measured family control on a continuous scale, for instance based on ownership shares in the hands of the family.
}

input or for the relationship between family firm and innovation output in a given sample. Following Van Essen, Otten, and Carberry (2015) and a long tradition of meta-analytic research in economics (Klomp \& De Haan, 2010; Stanley \& Doucouliagos, 2012), we used both bivariate ( $r$ ) and partial correlation coefficients $\left(r_{x y . z}\right)$ as our effect size estimates for the MARA procedure, which, in our case, capture the association between family firm and innovation input (Model 1) and between family firm and innovation output (Model 2) with a given set of $n$ control variables. Both effect sizes are easily interpretable and are scale-free measures of a linear relationship; thus, averages for the dependent and independent variables are not needed. The partial correlation coefficient can be computed from the $t$-statistics and degrees of freedom that are reported in the primary studies (Greene, 2003). MARA is a weighted least squares technique that assesses the relationship between moderator variables and effect size (e.g., family firm and innovation input or output) with the purpose of modeling previously unexplained variance in the effect size distribution (Lipsey \& Wilson, 2001). We used a weighted regression to account for differences in precision across effect sizes. The statistically preferable weighting variable is again $w$ (Hedges \& Olkin, 1985).

One of the unique advantages of using MARA is that it allows us to model the variance in the effect size distribution in light of country-level institutional variables that were not included in the primary studies (Carney et al., 2011). We used MARA to test the effect of two important institutional variables, as recent innovation literature has increasingly accounted for institutional moderators that affect firm innovation input and output (Barbosa \& Faria, 2011; Chesbrough, 1999; Hoskisson, Covin, Volberda, \& Johnson, 2011; Lundvall, 2010; Nelson, 1993). First, we controlled for the level of minority shareholder protection. In many cases, family firm owners do not possess the entirety of their firm's ownership shares but possess only a substantial fraction thereof (Anderson \& Reeb, 2003; Villalonga \& Amit, 2006). The remaining shares are in the hands of other, nonfamily (minority) owners, such as institutional owners or dispersed shareholders, who might have goals and interests that deviate from those of the family owners. To measure the impact of jurisdiction-level legal protection against the misuse of corporate assets by directors or large shareholders for their personal gain, we used the Spamann (2010) "anti-director rights index.” Strong anti-director laws prevent insiders from engaging in self-benefitting transactions and decision 
making based on their own utility function (Dyck \& Zingales, 2004). Second, structural differences among countries regarding the education level of the workforce might influence firms' ability to efficiently convert innovation input into output (Chesbrough, 1999). Since human capital-related arguments play an important role in our baseline Hypothesis $1 \mathrm{~b}$, studying the effect of the education level of the workforce appears particularly reasonable. We thus measured the availability of employees in the work force with a tertiary education, which reflects the proportion of the labor force that has a tertiary education as a percentage of the total labor force in that specific country (www. worldbank.org). Furthermore, we controlled for the prevalence of family firms in a country and for GDP per capita, as these variables may affect the availability of resources for and organizational behavior of family firms.

We also included a number of control variables related to the research designs and methodological approaches applied by the primary studies. First, we checked for effects caused by the use of different definitions of a family firm in the primary studies. As explained in the section on our independent variable, we distinguished between definitions based on ownership, management, ownership and management, and ownership or management (reference group). Second, as publicly listed companies might feel particular pressure to act in a strategically conforming way (Miller et al., 2013), we further controlled for whether the primary studies focused on publicly listed firms, mixed (publicly listed and private) firms, or private firms (reference category). Third, to account for measurement artifacts, we dummy-coded whether innovation input and output in the primary studies were logarithmically transformed or not (reference group). We further included several control variables to account for potential methodological artifacts. Since insignificant results are less likely to be published, we tested for the "file drawer problem" (Rosenthal, 1979) by including a dummy variable denoting whether a study was published or not (reference group). To account for publication outlet status effects, we included each publication's five-year ISI impact factor. To allow for the possibility that the focal relationship changes over time, we controlled for the median year of the sample window. To test whether the thoroughness of the primary study's methodological approach affected the observed effect sizes, we also included dummy variables indicating whether the primary studies used panel or cross-sectional (reference group) data, and whether they controlled for the endogeneity of family control on innovation input and output or not (reference group). Finally, we included dummy variables to assess whether the primary studies controlled for industry effects or not (reference group), since one could argue that family firms self-select into specific industries that are characterized by low or high levels of innovation. Finally, we controlled for whether the primary studies included year effects or not (reference group).

We also tested the robustness of the results against several model specification artifacts. To account for omitted variable bias, we controlled for the number of variables included in the regression. We also incorporated separate dummy variables that indicated whether the following firm and governance variables were included in the regressions in the primary studies: firm age (since innovation input and output might change over the life cycle of a firm), firm debt (since highly leveraged firms might lack financial resources to fund innovation [Kochhar \& David, 1996]), firm diversification (since diversification has been argued to correlate with lower investment in innovation [Kochhar \& David, 1996]), firm free cash flow (since slack resources might either impede or foster innovation [Greve, 2003]), firm risk (since risk likely affects investment preferences), firm size (since Schumpeter [1934] argued that only large firms have the ability and incentives to innovate), percentage of firm internationalization (since competition on a global base might encourage firms to pay more attention to innovation), prior firm performance (since evidence has suggested that performance below an aspiration level motivates family firms to temporarily prioritize financial over nonfinancial goals [Chrisman \& Patel, 2012]), prior firm $R \& D$ expenditures (since previously generated knowledge supports harvesting innovation input [Zahra \& George, 2002]), CEO duality (since CEOs holding dual positions might be particularly able to pursue their preferred investments), CEO tenure (since the CEO's ability to efficiently transform input into output might increase over time, while his or her proclivity to invest in innovation might simultaneously decrease), firm affiliated with a business group (since such structures might motivate family firms to avoid necessary innovations [Morck \& Yeung, 2003]), dual class shares (since dual class shares might aid family firms in pursuing their preferred investments), inside ownership (since inside ownership has been shown to affect the CEO's goals and motivation [Hoskisson et al., 2002]), and percentage ownership of largest owner (since the number of ownership stakes might be an indicator for 
TABLE 2

Meta-Analytic Correlation Matrix

\begin{tabular}{|c|c|c|c|c|c|c|}
\hline & Family firm & Family CEO & Founder CEO & Innovation input & Innovation output & Firm size \\
\hline Family firm & & $51,713(82)$ & $47,178(77)$ & $135,167(214)$ & $17,423(37)$ & $184,176(279)$ \\
\hline Family CEO & $0.23^{* *}$ & & $8,096(14)$ & $15,261(27)$ & $2,399(4)$ & $17,493(30)$ \\
\hline Innovation input & $-0.03 * *$ & -0.04 & $0.06^{+}$ & & $11,835(13)$ & $66,691(94)$ \\
\hline Innovation output & 0.01 & $0.07^{*}$ & $-0.10^{+}$ & $0.13^{* *}$ & & $17,312(26)$ \\
\hline Firm size & $-0.05 * *$ & -0.04 & $-0.09 * *$ & -0.01 & $0.23^{* *}$ & \\
\hline
\end{tabular}

Notes:Cells below the diagonal contain mean effect sizes (mean). Cells above the diagonal contain the total number of observations measured by the number of firms observed from primary studies $(n)$ and number of effect sizes $(k)$ in parentheses.

${ }^{+} p<.10$

${ }^{*} p<.05$

$* * p<.01$

the family's ability to pursue their preferences). Each of these variables was controlled for in at least $5 \%$ of all the effect sizes in the primary studies. To control for any further effects caused by the industrial context chosen for the primary studies, we also controlled for whether samples from primary studies included family firms participating in high-tech industries.

\section{RESULTS}

\section{MASEM Results}

Table 2 presents the meta-analytic correlation table. Cells below the diagonal represent 15 separate HOMAs and report the meta-analytic mean correlation for each relationship, which we used to run the MASEM analyses. Cells above the diagonal report the number of observations $(N)$ and the number of effect sizes $(k)$ on which the meta-analytic mean is based. Tables 3a, b, and c present the MASEM results.

Table 3a presents the MASEM results for Hypotheses $1 \mathrm{a}$ and $1 \mathrm{~b}$. As hypothesized, we find a negative and significant relationship between family firm and innovation input (Hypothesis 1a; $\beta=-.03$, $p<.01$ ) and a positive and significant association between family firm and innovation output (Hypothesis $1 \mathrm{~b} ; \beta=.03, p<.01) .{ }^{12}$ In line with previous findings, the relationship between innovation input

\footnotetext{
${ }^{12}$ The reported effect size represents innovation output in family firms when controlling for innovation input. In order to assess the overall effect of family firm status on innovation output, one has to correct this value by the lower innovation input in family firms (-.03). Since innovation input and innovation output are correlated by a factor of .13, the corrected effect of family firm status on innovation output can be calculated as: .03 $+(-.03$ * .13$)=$ .026 .
}

and innovation output is generally positive and significant (Acs \& Audretsch, 1988). The results in Table $3 \mathrm{~b}$ show that family firms invest even less in innovation if the CEO is a (nonfounder) member of the controlling family (Hypothesis $2 \mathrm{a} ; \beta=-.04, p<$ .01 as compared to $\beta=-.03$ in Table $3 a$ ) and that the positive effect of family firms on innovation output is even stronger if the CEO is a (nonfounder) member of the controlling family (Hypothesis $2 \mathrm{~b} ; \beta=.09$, $p<.01$ as compared to $\beta=0.03$ in Table 3a). ${ }^{13}$ $Z$-tests confirm the significant differences of family firms in general and those with family CEOs for innovation output only (Hypothesis $2 \mathrm{a} z=-1.17$; $p<$ .24 , Hypothesis $2 \mathrm{~b} z=10.21 ; p<.01$ ), resulting in strong support for Hypothesis $2 \mathrm{~b}$ but only weak support for Hypothesis 2a. Table 3c presents the MASEM results for Hypotheses $3 \mathrm{a}$ and $3 \mathrm{~b}$. We find that the founder CEO positively and significantly (instead of negatively and significantly, as was the case for family firms in general) influences innovation input (Hypothesis 3a; $\beta=.06, p<.01 ; z=$ $2.75 ; p<.01$ ), supporting Hypothesis 3a. However, contrary to our expectations, founder CEOs are negatively related to innovation output (Hypothesis $3 \mathrm{~b} ; \beta=-.09, p<.01 ; z=-43.71 ; p<.01),{ }^{14}$ leading us to reject Hypothesis $3 \mathrm{~b}$.

\footnotetext{
${ }^{13}$ Correcting for lower innovation input in family firms with family CEOs, this value must be adapted to: $.09+(-.04 \times 0.14)=.084$ if one is interested in the overall innovation output of family firms with family CEOs.

${ }^{14}$ Correcting for higher innovation input in family firms with founder CEOs, this value must be adapted to: $-.09+(0.06 \times 0.14)=-0.82$ if one is interested in the overall innovation output of family firms with founder CEOs.
} 
TABLE 3a

Pooled MASEM Results

\begin{tabular}{lcc}
\hline \multicolumn{1}{c}{ Predictors } & Innovation input & $\begin{array}{c}\text { Innovation } \\
\text { output }\end{array}$ \\
\hline $\begin{array}{l}\text { Family firm } \\
\quad \text { (Hypothesis } \\
\quad \text { 1a, Hypothesis 1b) }\end{array}$ & $-\mathbf{0 . 0 3}(-\mathbf{4 . 9 6})^{* *}$ & $\mathbf{0 . 0 3 ( 4 . 3 1 ) ^ { * * }}$ \\
$\begin{array}{l}\text { Firm size } \\
\text { Innovation input }\end{array}$ & $-0.01(-1.87)$ & $\mathbf{0 . 2 3}(\mathbf{3 9 . 1 4})^{* *}$ \\
Harmonic mean $n$ & & $\mathbf{0 . 1 3}(\mathbf{2 2 . 4 1})^{* *}$ \\
$\quad$ (firms observed) & 26,376 & \\
$\mathrm{X}^{2}$ & $0.00(1.00)$ & \\
GFI & 1.00 & \\
RMSEA & 0.00 & \\
\hline
\end{tabular}

Notes: $t$-values are given in parentheses; $G F I=$ Goodness of fit statistics; RMSEA = Root mean square error of approximation.

${ }^{* *} p<.01$

\section{Post Hoc MARA Results}

Table 4 presents the MARA results. The results for Model 1 show how several control variables affect the effect size of the family firm-innovation input relationship, and the results for Model 2 show how these variables affect the effect size of the family firm-innovation output relationship.

Model 1 fits the data reasonably well $\left(R^{2}=.25\right)$. Regarding country-level differences, we find that the level of minority shareholder protection, as captured by the anti-director rights index (Spamann, 2010), significantly strengthens the negative association between family control and innovation input $(p<.05)$. In other words, when the level of minority shareholder protection is higher, family firms have even lower innovation input than when the level of minority shareholder

TABLE $3 \mathbf{b}$

Family CEO MASEM Results

\begin{tabular}{lcc}
\hline \multicolumn{1}{c}{ Predictors } & Innovation input & $\begin{array}{c}\text { Innovation } \\
\text { output }\end{array}$ \\
\hline $\begin{array}{l}\text { Family CEO } \\
\quad \text { (Hypothesis }\end{array}$ & $-\mathbf{0 . 0 4}(\mathbf{- 3 . 7 5})^{* *}$ & $\mathbf{0 . 0 9}(\mathbf{8 . 1 8})^{* *}$ \\
$\quad$ 2a, Hypothesis $\mathbf{b})$ & & \\
Firm size & $-0.01(-1.08)$ & $\mathbf{0 . 2 3}(\mathbf{2 2 . 6 6})^{* *}$ \\
Innovation input & & $\mathbf{0 . 1 4}(\mathbf{1 3 . 1 0})^{* *}$ \\
Harmonic mean $n$ & 8,611 & \\
$\quad$ firms observed) & & \\
$\mathrm{X}^{2}$ & $0.00(1.00)$ & \\
GFI & 1.00 & \\
RMSEA & 0.00 & \\
\hline
\end{tabular}

Notes: $t$-values are given in parentheses; $G F I=$ Goodness of fit statistics; RMSEA = Root mean square error of approximation.

${ }^{* *} p<.01$
TABLE 3C

Founder CEO MASEM Results

\begin{tabular}{lcc}
\hline \multicolumn{1}{c}{ Predictors } & Innovation input & $\begin{array}{c}\text { Innovation } \\
\text { output }\end{array}$ \\
\hline $\begin{array}{l}\text { Founder CEO } \\
\text { (Hypothesis }\end{array}$ & $\mathbf{0 . 0 6}(\mathbf{5 . 5 2})^{* *}$ & $\mathbf{- 0 . 0 9 ( - \mathbf { 8 . 4 7 } ) ^ { * * }}$ \\
$\quad$ 3a, Hypothesis $3 \boldsymbol{b})$ & & \\
$\begin{array}{l}\text { Firm size } \\
\text { Innovation input }\end{array}$ & $-0.00(-0.43)$ & $\mathbf{0 . 2 2}(\mathbf{2 1 . 5 0})^{* *}$ \\
$\begin{array}{l}\text { Harmonic mean } n \\
\quad \text { (firms observed) }\end{array}$ & 5,377 & $\mathbf{0 . 1 4}(\mathbf{1 3 . 2 6})^{* *}$ \\
$\mathrm{X}^{2}$ & & \\
GFI & $0.00(1.00)$ & \\
RMSEA & 1.00 & \\
\hline
\end{tabular}

Notes: $t$-values are given in parentheses; $G F I=$ Goodness of fit statistics; RMSEA = Root mean square error of approximation.

${ }^{* *} p<.01$

protection is lower. The negative and marginally significant coefficient for the ownership definition dummy $(p<.10)$ indicates that studies that have based their definition of a family firm on ownership have found that family firms invest even less in innovation. We also find significant effects for several measurement, methodological, and model specification dummies: In studies that logarithmically transformed the dependent variables $(p<.01)$ and in studies that controlled for prior firm performance $(p<.10)$, the effect size of the family firm-innovation input relationship is significantly less negative. In studies that were published in journals with a higher ISI impact factor $(p<.01)$, more recent studies (i.e., those that have a higher median year of the sample window; $p<.01)$, studies that used a panel design $(p<.10)$, and studies that controlled for firm debt $(p<.05)$, the effect sizes of the family firm-innovation input relationship are significantly more negative, indicating that those studies have found that family firms have even lower innovation input. Moreover, studies based on samples with a higher (logarithm of) GDP per capita have found a more negative effect size of the family firm-innovation input relationship $(p<.01)$.

Model 2 presents the MARA results regarding innovation output. The model fits the data very well $\left(R^{2}=.48\right)$. Regarding country-level differences, the availability of highly educated workers in a country strengthens the positive effect of family firms on innovation output ( $p<.05$ ). In other words, when the proportion of workforce with a tertiary education is high in a country, family firms have even higher innovation output than nonfamily firms do. Moreover, 
we find that the effect size of the family firminnovation output relationship is significantly more positive for studies that have included both publicly listed and private firms $(p<.10)$, as compared to studies focusing solely on private firms. The effect size of the family firm-innovation output relationship has been significantly less positive in studies that logarithmically transformed the dependent variable $(p<.05)$, studies that controlled for firm debt $(p<.05)$, studies that controlled for the percentage of firm internationalization $(p<$ .01 ), and studies that included family firms in hightech industries $(p<.01)$. The effect size of the family firm-innovation output relationship is significantly more positive when the ISI impact factor of the journal is high $(p<.05)$, when studies controlled for prior firm performance $(p<.10)$, and when the prevalence of family firms in the country is high $(p<.05)$. Table 5 summarizes the hypotheses, the methodological approaches to test the hypotheses, and the results of the MASEM and MARA calculations.

\section{DISCUSSION}

Based on a meta-analysis of 108 primary studies covering 42 countries, we showed that while family firms invest significantly less in innovation than nonfamily firms do, their innovation output, ceteris paribus, is higher. The engagement of a family CEO leads to a further slight decrease in innovation input, but simultaneously increases the innovation output of the firm. The picture, however, is different when the founder leads the firm: in such cases, innovation input is increased (as expected), while, contrary to our expectations, innovation output is decreased. We conjecture that this unexpected finding might result from such firms' limited access to trusted network partners, firm-internal human capital, and beneficial internal processes, which might only build up over time. As the post hoc test reveals, the associations among family firms, innovation input, and innovation output are sensitive to institutional factors: a higher level of minority shareholder protection further decreases innovation input in family firms, and the availability of a well-educated workforce supports family firms in their attempts to efficiently turn innovation input into output.

\section{Theoretical and Empirical Contributions and Avenues for Further Research}

Research on innovation. The findings of our study yield important insights for the literature on innovation. First and foremost, our findings inform the ongoing debate on the antecedents of innovation input and output (for a summary, see Ahuja et al., 2008). We thereby extend and challenge extant literature by studying a determinant of innovation that affects innovation input and output in opposite ways-through family control. While previous research has noted the potential existence of such factors-e.g., centralization and formalization (Damanpour, 1991; Pierce \& Delbecq, 1977)—this study, to the best of our knowledge, is one of the first to systematically investigate the effects of such a factor on innovation input and output simultaneously, and to provide a coherent and consistent theoretical explanation of such patterns. The finding that family control affects innovation input negatively, but innovation output positively, challenges our knowledge on innovation, since it demonstrates that findings on the antecedents of innovation input cannot be easily generalized to innovation output. In other words, some of the previously identified drivers of innovation might indeed be "double-edged swords" that foster innovation input but hamper innovation output. On the other hand, previous research might also have identified several "false enemies;" that is, factors that impede innovation input, but at the same time-like family control-increase the firm's conversion rate and ultimately imply higher innovation output.

Further, the findings of our article can be viewed as a call for a shift in scholarly attention to the "conversion rate" of the innovation process-that is, how much units of output can be generated by one unit of innovation input ${ }^{15}$-and in particular the antecedents of this conversion rate. The majority of firms worldwide-such as businesses in emerging economies, new ventures, or other small- and medium-sized companies-operate under substantial resource constraints and, since they are unable to raise their investments in innovation to catch up with competition, are thus required to work particularly efficiently-and constantly increase their efficiency in such competitive environments. As such, the notion of conversion rates and efficient or parsimonious innovation processes (Verona, 1999) is particularly important. Understanding the factors that either increase or impede the conversion of innovation input into innovation output will help advance scholarly knowledge about firms' competitive advantages stemming from innovation, and will also be of

\footnotetext{
${ }^{15}$ In mathematical terms, conversion_rate $=\delta$ (Innovation Output) / $\delta$ (Innovation_Input).
} 
TABLE 4

MARA Results

\begin{tabular}{|c|c|c|}
\hline Variable & Model 1 FF-innovation input & Model 2 FF-innovation output \\
\hline \multicolumn{3}{|l|}{ Institutional variables } \\
\hline Anti-director rights & $-0.02(0.01)^{*}$ & $0.10(0.06)$ \\
\hline Prevalence of family firms & $-0.01(0.08)$ & $1.67(0.65)^{*}$ \\
\hline Ln GDP per capita & $-0.03(0.01)^{* *}$ & $-0.09(0.15)$ \\
\hline \multicolumn{3}{|l|}{ Family firm definition } \\
\hline Ownership and management & $-0.02(0.02)$ & $0.12(0.17)$ \\
\hline \multicolumn{3}{|l|}{ Type of family firm } \\
\hline Publicly listed & $0.01(0.02)$ & $0.02(0.10)$ \\
\hline Mixed (publicly listed and private) & $-0.03(0.04)$ & $0.15(0.08)^{+}$ \\
\hline \multicolumn{3}{|l|}{ Measurement artifacts } \\
\hline Logarithmically transformed & $0.08(0.03)^{* *}$ & $-0.12(0.05)^{*}$ \\
\hline Panel design & $-0.04(0.02)^{+}$ & $-0.17(0.11)$ \\
\hline Endogeneity check & $0.01(0.03)$ & $0.02(0.03)$ \\
\hline Industry effects & $-0.01(0.06)$ & $0.23(0.17)$ \\
\hline Year effects & $-0.01(0.04)$ & $-0.03(0.06)$ \\
\hline \multicolumn{3}{|l|}{ Model specification artifacts } \\
\hline Number of variables in regression & $-0.00(0.00)$ & $0.00(0.01)$ \\
\hline Firm age & $0.08(0.06)$ & $0.12(0.08)$ \\
\hline Firm debt & $-0.10(0.04)^{*}$ & $-0.39(0.18)^{*}$ \\
\hline Firm diversification & $0.03(0.06)$ & $-0.67(0.42)$ \\
\hline Firm free cash flow & $-0.02(0.05)$ & $-0.32(0.26)$ \\
\hline Firm risk & $-0.05(0.07)$ & $-0.23(0.26)$ \\
\hline Firm size & $-0.02(0.08)$ & $0.03(0.17)$ \\
\hline Percentage ownership of largest owner & $0.01(0.03)$ & $-0.01(0.08)$ \\
\hline Sample of FFs include high-tech industries ${ }^{a}$ & $0.02(0.01)$ & $-0.21(0.06)^{* *}$ \\
\hline$R^{2}$ & 0.25 & 0.48 \\
\hline K & 312 & 158 \\
\hline$Q_{\text {model }}(p)$ & $116.99(0.00)$ & $112.93(0.00)$ \\
\hline$Q_{\text {residual }}(p)$ & $361.87(0.00)$ & $124.05(0.46)$ \\
\hline$V$ & 0.00375 & 0.00233 \\
\hline
\end{tabular}

Notes: Unstandardized regression coefficients are presented with standard errors in parentheses. $k$ is the number of effect sizes; $Q$ is the homogeneity statistic with its probability in parentheses; and $V$ is the random effects variance component.

${ }^{a}$ High-tech industries include the following: electronics and computers, pharmaceuticals, and air spacecraft.

${ }^{+} p<.10$

${ }^{*} p<.05$

${ }^{* *} p<.01$

outmost interest to practitioners. Through this study, we extend extant scholarly knowledge by identifying the committed and informed monitoring of family owners; the family firms' unique access to a trusted, firm-external network; as well as tacit knowledge and routines available in family firms as facilitators of the efficient conversion of innovation input into innovation output. 
TABLE 5

Summary of Hypothesized Effects

\begin{tabular}{|c|c|c|c|}
\hline Hypotheses & Methodology & Statistical results & Interpretation \\
\hline \multicolumn{4}{|l|}{ Baseline hypotheses } \\
\hline $\begin{array}{l}\text { 1a: Family firms have lower innovation input } \\
\text { compared to nonfamily firms. }\end{array}$ & MASEM & Table 3a: $-0.03(p<0.01)$ & Hypothesis 1a supported \\
\hline $\begin{array}{l}\text { 1b: Family firms have higher innovation output } \\
\text { compared to nonfamily firms. }\end{array}$ & MASEM & $\begin{array}{l}\text { Table 3a: } 0.03(p<0.01) \\
\left.\text { Corrected for lower input (see } \mathrm{fn}^{\mathrm{a}} 12\right): 0.026\end{array}$ & Hypothesis $1 \mathrm{~b}$ supported \\
\hline \multicolumn{4}{|l|}{ Leadership variables } \\
\hline $\begin{array}{l}\text { 3a: Family firms with founder CEO have higher } \\
\text { innovation input than those without } \\
\text { a founder CEO. }\end{array}$ & MASEM & $\begin{array}{l}\text { Table 3c: } .06(p<.01) \\
\text { Table 3a vs. 3c: } z=2.75(p<.01)\end{array}$ & Hypothesis 2 b supported \\
\hline $\begin{array}{l}\text { 2b: Family firms with family CEOs have higher } \\
\text { innovation output than those without } \\
\text { a family CEO. }\end{array}$ & MASEM & $\begin{array}{l}\text { Table 3b: } 0.09(p<0.01) \\
\text { Table 3a vs. 3b: } z=10.21(p<0.01) \\
\text { Corrected for lower input (see fn. 13): .084 }\end{array}$ & Hypothesis 3a supported \\
\hline \multicolumn{4}{|l|}{ Country-level moderators_-post hoc test } \\
\hline Increased minority shareholder protection & MARA & Table 4: $-0.02(p<0.05)$ & $\begin{array}{l}\text { Even lower innovation input } \\
\text { in family firms, as effect } \\
\text { sizes more negative }\end{array}$ \\
\hline $\begin{array}{l}\text { Effect of workforce with higher education in the } \\
\text { respective country }\end{array}$ & MARA & Table 4: $1.54(p<0.05)$ & $\begin{array}{l}\text { Even higher innovation } \\
\text { output in family firms, as } \\
\text { effect sizes more positive }\end{array}$ \\
\hline
\end{tabular}

${ }^{\text {a }} \mathrm{fn}$. = footnote; for calculations of how to transform values controlling for innovation input into the overall effects on innovation output, please refer to the respective footnotes in the results section.

${ }^{\mathrm{b}}$ In order to test whether the presence of family CEOs or founder CEOs affects the baseline hypotheses, the coefficients derived from the models referring to the baseline hypotheses (Table 3a) need to be compared with the coefficients derived from the models focusing on family CEOs (Table 3b) or founder CEOs (Table 3c), respectively.

Moreover, family owners' monitoring and their efficacious deployment of internal and external resources, which are part of the organizations' resource orchestration (Sirmon, Hitt, \& Ireland, 2007; Sirmon et al., 2011), can be considered an important and useful dynamic capability of those firms (Teece et al., 1997). The specific mechanisms underlying the resource orchestration in family firms challenge and extend prior knowledge on innovation in organizations. First, while control throughout the innovation process has often been portrayed as detrimental to creativity and information sharing (Simons, 1995), we argue that the monitoring of family owners spurs the process, since those owners are highly committed to the firm, interested in an efficient conversion process, and can be characterized as informed and sophisticated owners who possess rich knowledge of the firm, its products and services, and its environment. Second, we also draw attention to how a focus on nonfinancial goals can entail competitive advantages for firms, not only with regard to superior reputation as identified by previous studies (Zellweger, Eddleston, \& Kellermanns, 2010), but also in relation to innovation. As we argue, in contrast to prior research that has mainly focused on the private benefits that family owners might extract from their organizations, to the detriment of these firms (e.g., Dyck \& Zingales, 2004), the pursuit of nonfinancial goals, and in particular the desire to build and maintain long-lasting and trusted relationships with firm-internal and -external stakeholders, results in routines, tacit knowledge, and superior network access that help spur the conversion of innovation input into innovation output.

Our findings, in particular the results on innovation output in family firms with later-generation, as opposed to first-generation, CEOs, show that those dynamic capabilities cannot be acquired in the short 
term, but that they are developed and built up over an extended period of time. As such, our study also draws attention to the temporal perspective of firms' competitive advantages with regard to innovation, which might accumulate over time. In sum, findings from our study not only offer important insights for owners and managers of family firms, but also for those of nonfamily firms that are encouraged to learn from the efficient innovation processes of family firms.

Indeed, the identified mechanisms that lead to superior conversion rate and higher innovation output in family firms are not "bloodline issues," but are caused by the characteristic governance structures and goals within those firms. As such, they could also be emulated in other blockholding arrangements, such as pension funds (Hoskisson et al., 2002), trusts (Thomsen \& Pedersen, 1996), or state-ownership enterprises (Shleifer, 1998). In particular, dedicated (as opposed to transient) owners (Connelly, Tihanyi, Certo, \& Hitt, 2010) might aim to learn from family firms in terms of how to achieve "active ownership involvement," which includes the committed and informed monitoring of innovation processes, as well as dedication to stakeholders.

Research on innovation in family firms. Our research also attempts to reconcile and extend prior findings on innovation in family firms, a topic that is of substantial practical and scholarly interest (De Massis et al., 2013). While our results confirm prior empirical findings (e.g., Block, 2012; Chrisman \& Patel, 2012; Gómez-Mejía et al., 2014; Schmid, Achleitner, Ampenberger, \& Kaserer, 2014) that innovation input is lower in family firms than in nonfamily firms, we challenge research on family firm innovation by arguing and empirically showing that this lower input level does not translate into a lower output level; instead, our findings indicate that family firms are particularly well suited to efficiently using invested resources (e.g., Carney, 2005; Sirmon et al., 2011)—and thus to achieving higher innovation output-compared to nonfamily firms, despite the formers' limited level of innovation input.

We argue that both effects-lower innovation input and higher innovation output - are caused by the same set of family firm idiosyncrasies. First, wealth concentration implies specific attitudes toward risk and uncertainty, and thus lowers the amount of financial resources dedicated to innovation projects, which are a priori uncertain; however, at the same time it also motivates family owners to monitor the efficiency of the innovation process in order to further reduce uncertainty. Second, the family owners' high level of power and control over the firm renders them able to enforce their personal investment preferences, but also empowers them to efficaciously monitor the innovation process. Third, the focus on nonfinancial goals dis-incentivizes family owners to raise external money, and thus limits their innovation input. At the same time, the existence of nonfinancial, alongside financial, goals, also leads to the development of capabilities, tacit knowledge, and network access over time, which ultimately augment the innovation process. Our study thus also informs scholarly discussions on whether family influence is beneficial or detrimental to firm success (O'Boyle et al., 2012; Wagner, Block, Miller, Schwens, \& Xi, 2015).

In addition to the empirical contribution and reconciliation of prior results, the findings from our study have important implications for theory on family firm innovation. Given the complex nature of firm-level innovation, building on arguments from a single extant theory to explain family firm innovation is insufficient. For instance, the behavioral agency model (Wiseman \& Gómez-Mejía, 1998) is able to explain lower innovation input, yet it falls short in explaining family firms' innovation output. The resource-based view (Barney, 1991; Carnes \& Ireland, 2013; Sirmon \& Hitt, 2003), by contrast, captures family firms' advantages in orchestrating resources and in efficiently turning innovation input into valuable output; however, it does not convincingly predict family firms' lower innovation input. In line with recent calls to build on multi-theory approaches to fully comprehend family business behavior (Miller et al., 2014), we argue that in order to understand family firm innovation, one needs to take one step back and consider the specific elements that render family firms different from nonfamily firms; these elements include the family's level of control over a firm, the concentration of the family's wealth, and the nonfinancial goals of family firm owners. These factors, in turn, affect both the investment decisions of a family firm (which are often explained by behavioral agency models) and the conversion process of innovation input into output in those firms (which is often explained by resource orchestration).

Research on family firm heterogeneity. Our findings also contribute to recent research on heterogeneity among family firms (Chua et al., 2012), because we find substantial variance within our sample that is dependent on who the family firm's CEO is. First, the findings of our study have implications for research on the advantages and disadvantages of leadership professionalization (Anderson \& Reeb, 2003; GómezMejía et al., 2003; Miller et al., 2014; Stewart \& Hitt, 
2012) in family firms. An ongoing debate in family firm research aims to answer the question regarding whether family CEOs are beneficial or detrimental to firm performance. As some researchers have argued, the emotional attachment of the family CEO will lead to outstanding commitment (e.g., Sciascia \& Mazzola, 2008). Other researchers, however, have argued that family CEOs are often selected for altruistic and nepotistic reasons, and that they thus underperform (Claessens, Djankov, Fan, \& Lang, 2002). Our study reveals that management by a family CEO further impedes investment of resources in innovation, but simultaneously fosters efficiency in the use of those resources. Our study thus indicates that firms with a family CEO might benefit from the use of incentive systems to foster investment in innovation, whereas family firms with professionalized managementi.e., a nonfamily CEO-should focus on creating and maintaining valuable social and human capital within the organization to become (and remain) innovative.

Second, our study challenges the emerging stream of research aiming to disentangle founder effects (Block, 2012; Block, Miller, Jaskiewicz, \& Spiegel, 2011; Jayaraman et al., 2000; Miller et al., 2011). Previous studies in this research stream have shown that founder-led firms differ from other firms and that they often outperform both nonfamily firms and family firms that are controlled by later generations (Andres, 2008; Miller et al., 2007). Our data confirm findings from prior studies showing that founder firms have high levels of innovation input (Block et al., 2011). Surprisingly, however, and contrary to our conjecture, firms with a founder CEO exhibit lower levels of innovation output. We explain this initially unexpected finding by referring to such firms' inferior levels of efficient organizational routines, limited firm-internal tacit knowledge, and less privileged network access relative to later-generation family firms: as these family firmspecific advantages build up over time (Sirmon \& Hitt, 2003), they might thus be less prevalent in founder-led firms. ${ }^{16}$ Moreover, founder CEOs might

\footnotetext{
${ }^{16}$ For instance, the level of trust that external network partners place in the CEO might be higher for family CEOs than for founder CEOs. Research on trust has shown that trust increases over time (Gulati, 1995). Since family CEOs, who have often taken over responsibility from a family member, are frequently introduced to the family firm's network early in their life (for instance, at important firm celebrations or during internships), the network partners of the family firm can, over time, build up more substantial trust in the family CEO than in a founder CEO.
}

suffer from potential over-investment in less promising innovation projects (cf. Nieß \& Biemann, 2014), since such leaders face "less resistance to investing in poor projects" (Fahlenbrach, 2009: 462). The unexpected finding of a negative impact of founder presence on innovation output might stimulate further in-depth research on the positive and negative effects of founders on firm behavior and on the associated competitive advantages and disadvantages. In particular, researchers might study how the innovation input and output of founder-led firms change as the tenure of the CEO increases.

Research on the relevance of institutional factors for innovation input and output. The results from our post hoc analyses show that the focal relationships also depend on country-level factors; in other words, the innovative behavior of family and nonfamily firms differs in their susceptibility to the influence of institutions.

First, our results show that high levels of minority shareholder protection (La Porta, Lopez-de-Silanes, Shleifer, \& Vishny, 1998) strengthen the negative effect of family control on innovation input. As such, our findings challenge extant research on the benefits of shareholder protection (e.g., Djankov, La Porta, Lopez-de-Silanes, \& Shleifer, 2008). Several recent law and economics studies might help explain this initially puzzling effect (Anabtawi, 2005; Anabtawi \& Stout, 2008; Gordon, 2008). Belloc (2013) argued that individual shareholders possess individual interests, and, in particular, that they engage in intershareholder opportunism strategies because they expect ex post expropriation. High levels of minority shareholder protection thereby provide individual shareholders with powerful rights to block important strategic moves and thus encourage defensive strategies (Belloc, 2013). Individual minority shareholders might therefore act as traders instead of owners (Hendry, Sanderson, Barker, \& Roberts, 2006), and may focus on short-term financial performance (Lazonick \& O'Sullivan, 2000). Consequently, minority shareholder protection might impede, rather than foster, innovation input in family firms.

Second, our results further extend research by showing that not all organizations might equally benefit from institutional factors. While innovation scholars have long argued that organizations' innovation output benefits from a highly educated workforce in a country (Furman, Porter, \& Stern, 2002; Varsakelis, 2006), we show that this effect is even stronger for family firms. We argue that this stronger effect for family firms arises because of family firms' pronounced reliance on the human capital of their 
employees and the support of their network members throughout the innovation process.

\section{Limitations}

As with any empirical work, this meta-analysis faces a number of limitations. First, the effect sizes presented in this study are only modest, yet they are in line with the sizes of correlations reported in other recent meta-analyses in the management literature (Carney et al., 2011; Dalton, Daily, Certo, \& Roengpitya, 2003; Post \& Byron, 2015). Moreover, even a seemingly trivial increase in innovation output often translates into significant additional earnings, given the positive link between innovation output and firm performance (Capon, Farley, \& Hoenig, 1990; Rosenbusch, Brinckmann, \& Bausch, 2011). This increase in innovation output matters all the more given that family firms represent the predominant type of firms across the globe.

As with any meta-analysis, our study is constrained by the limitations inherent in the primary studies that we analyzed. As such, potential limitations in the original study designs might distort our findings. We aimed to mitigate the risk of such biases by including a range of control variables intended to identify the effects of potential measurement, methodological, and model specification artifacts into our MARAs. For instance, we included a dummy variable indicating whether the primary studies controlled for endogeneity (no significant effect). Moreover, in Appendix A, we provide an overview of the research approach of the primary studies (e.g., questionnaire vs. archival data) and the response rates (if available).

Furthermore, meta-analytic studies often suffer from a "file-drawer problem" (Rosenthal, 1979) caused by overreliance on published work and a neglect of unpublished work. Since studies with nonsignificant results often remain unpublished, such a bias would imply that the results are, in reality, weaker than suggested by the results of the meta-analysis. To address this problem, we first aimed to include unpublished work, such as working papers and unpublished theses. Second, we controlled for the journals' impact factor in the MARA and included a dummy variable indicating whether the study was published. Third, we conducted robustness tests focusing solely on published papers in order to test whether the results become stronger if unpublished work remains unconsidered. ${ }^{17}$ Taken together, while

\footnotetext{
${ }^{17}$ Details available from the authors upon request.
}

file-drawer problems cannot be entirely ruled out, the robustness tests that we conducted indicate that our results do not suffer from such biases, and provide further empirical support for our hypotheses.

A further source of potential bias lies in the diversity of operationalizations used to capture the effect of "family firms." We aimed to address this issue by creating four categories of family firms to differentiate between various approaches to conceptualizing family control, and use those variables as controls in the HOMA and MARA procedures. However, potential differences among the primary studies-for instance, in the minimum threshold values for ownership shares-might still have affected our findings. Future research is thus encouraged to investigate whether specific family firm characteristics, besides the ones discussed in this study, impact family firm innovation input and output. We also encourage researchers to use continuous measures of family control (König et al., 2013), instead of a dichotomous distinction between family and nonfamily firms, in further studies.

Moreover, innovation input was typically operationalized as R\&D expenditures standardized by firm size. However, small and medium-sized businesses in particular frequently shy away from formally budgeting resources for R\&D purposes and from reporting them as such; instead, employees informally dedicate a substantial portion of their work time to creating ideas for product and process improvement.

In addition, the measures for innovation output are less than perfect. For instance, scholars have criticized the use of patent data as a variable for innovation output because patents may not transfer directly into new product sales (Pakes \& Griliches, 1980). Moreover, we could not differentiate between different kinds of innovation activities. For instance, König et al. (2013) argued that family firms face specific dilemmas when discontinuous technologies occur, and in the same vein, Patel and Chrisman (2014) found that family firms invest less in exploration. One may assume that family firms invest in continuous improvements in their core areas (Pennings \& Harianto, 1992; Sydow, Schreyögg, \& Koch, 2009), and that they thereby become "innovators" and experts in a rather narrow area (cf. Levitt \& March, 1988). To gain an even better understanding of family firm innovation, more research based on a variety of nuanced innovation output variables, in conjunction with the leadership variables discussed in this study, is needed. 
Our study is further limited because it cannot capture all heterogeneity that exists among family firms. While we explicitly studied the effects of a family and founder CEO, we could not study the potential effects of, for instance, the variance of emphasis on different nonfinancial goals of family owners (Kotlar \& De Massis, 2013), which have been shown to affect innovation in family firms (Kammerlander \& Ganter, 2015). Further research might thus systematically study the effect of further country-, firm-, and familylevel variables on the family firm-innovation input or output relationships.

\section{CONCLUSION}

Family firms invest less in innovation projects than do nonfamily firms. However, this finding does not imply that family firms are less innovative than nonfamily firms. The results from our meta-analysis of 108 primary studies from 42 countries suggest that family firms are particularly well-suited to deploying resources in an efficacious way and to turning innovation input into innovation output. This effect depends on the institutional context, and it is particularly strong when the CEO is from the family but turns to the opposite when the founder remains the CEO. These findings are relevant not only for family firms, as the predominant type of firm around the globe, but also our general understanding of innovation processes.

\section{REFERENCES}

Acs, Z. J., \& Audretsch, D. B. 1988. Innovation in large and small firms: An empirical analysis. The American Economic Review, 78: 678-690.

Adams, R., Bessant, J., \& Phelps, R. 2006. Innovation management measurement: A review. International Journal of Management Reviews, 8: 21-47.

Ahuja, G., Lampert, C. M., \& Tandon, V. 2008. Moving beyond Schumpeter: Management research on the determinants of technological innovation. The Academy of Management Annals, 2: 1-98.

Alexiev, A. S., Jansen, J. J., Van den Bosch, F. A., \& Volberda, H. W. 2010. Top management team advice seeking and exploratory innovation: The moderating role of TMT heterogeneity. Journal of Management Studies, 47: 1343-1364.

Almeida, P., Song, J., \& Grant, R. M. 2002. Are firms superior to alliances and markets? An empirical test of cross-border knowledge building. Organization Science, 13: 147-161.
Anabtawi, I. 2005. Some skepticism about increasing shareholder power. UCLA Law Review, 53: 561-599.

Anabtawi, I., \& Stout, L. 2008. Fiduciary duties for activist shareholders. Stanford Law Review, 60: 1255-1308.

Anderson, R., Duru, A., \& Reeb, D. 2009. Family preferences and investment policy: Evidence from capital expenditures and RED spending, Working Paper. American University, Washington, DC.

Anderson, R. C., Duru, A., \& Reeb, D. M. 2012. Investment policy in family controlled firms. Journal of Banking \& Finance, 36: 1744-1758.

Anderson, R. C., Mansi, S. A., \& Reeb, D. M. 2003. Founding family ownership and the agency cost of debt. Journal of Financial Economics, 68: 263-285.

Anderson, R. C., \& Reeb, D. M. 2003. Founding-family ownership and firm performance: Evidence form the S\&P 500. The Journal of Finance, 58: 1301-1328.

Andres, C. 2008. Large shareholders and firm performanceAn empirical examination of founding-family ownership. Journal of Corporate Finance, 14: 431-445.

Andriopoulos, C., \& Lewis, M. W. 2009. Exploitationexploration tensions and organizational ambidexterity: Managing paradoxes of innovation. Organization Science, 20: 696-717.

Bammens, Y., Notelaers, G., \& Van Gils, A. 2015. Implications of family business employment for employees' innovative work involvement. Family Business Review, 28: 123-144.

Barbosa, N., \& Faria, A. P. 2011. Innovation across Europe: How important are institutional differences? Research Policy, 40: 1157-1169.

Barney, J. 1991. Firm resources and sustained competitive advantage. Journal of Management, 17: 99-120.

Beatty, R. P., \& Zajac, E. J. 1994. Managerial incentives, monitoring, and risk bearing: A study of executive compensation, ownership, and board structure in initial public offerings. Administrative Science Quarterly, 39: 313-335.

Becheikh, N., Landry, R., \& Amara, N. 2006. Lessons from innovation empirical studies in the manufacturing sector: A systematic review of the literature from 1993-2003. Technovation, 26: 644-664.

Belloc, F. 2013. Law, finance and innovation: The dark side of shareholder protection. Cambridge Journal of Economics, 37: 863-888.

Bergh, D. D., Aguinis, H., Heavey, C., Ketchen, D. J., Boyd, B. K., Su, P., Lau, C. L. L., \& Joo, H. 2014. Using metaanalytic structural equation modeling to advance strategic management research: Guidelines and an empirical illustration via the strategic leadershipperformance relationship. Strategic Management Journal,37: 477-497. 
Berrone, P., Cruz, C., \& Gómez-Mejía, L. R. 2012. Socioemotional wealth in family firms: Theoretical dimensions, assessment approaches, and agenda for future research. Family Business Review, 25: 258-279.

Berrone, P., Cruz, C., Gómez-Mejía, L. R., \& Larraza-Kintana, M. 2010. Socioemotional wealth and corporate responses to institutional pressures: Do family-controlled firms pollute less? Administrative Science Quarterly, 55: 82-113.

Bertrand, M., Johnson, S., Samphantharak, K., \& Schoar, A. 2008. Mixing family with business: A study of Thai business groups and the families behind them. Journal of Financial Economics, 88: 466-498.

Bianco, M., Bontempi, M. E., Golinelli, R., \& Parigi, G. 2013. Family firms' investments, uncertainty and opacity. Small Business Economics, 40: 1035-1058.

Bijmolt, T. H. A., \& Pieters, R. G. M. 2001. Meta-analysis in marketing when studies contain multiple measurements. Marketing Letters, 12: 157-169.

Bitard, P., Edquist, C., Hommen, L., \& Rickne, A. 2008. Reconsidering the paradox of high R\&D input and low innovation: Sweden. In C. Edquist, \& L. Hommens (Eds.), Small country innovation systems: Globalization, change and policy in Asia and Europe: 237-280. Cheltenham, UK: Edward Elgar Publishing.

Block, J., Miller, D., Jaskiewicz, P., \& Spiegel, F. 2011. Innovation in founder and family firms: Entrepreneurial versus nurturer identities of owners. Frontiers of Entrepreneurship Research, 31: 437-450.

Block, J. H. 2012. R\&D investments in family and founder firms: An agency perspective. Journal of Business Venturing, 27: 248-265.

Buckley, P., Devinney, T., \& Tang, R. 2013. Meta-analytic research in international business and international management. Advances in International Management, 26: 263-297.

Burgelman, R. A. 1991. Intraorganizational ecology of strategy making and organizational adaptation: Theory and field research. Organization Science, 2: 239-262.

Bushee, B. J. 1998. The influence of institutional investors on myopic R\&D investment behavior. The Accounting Review, 73: 305-333.

Cabrera-Suarez, K., Saa-Perez, P., \& Garcia-Almeida, D. 2001. The succession process from a resource- and knowledge-based view of the family firm. Family Business Review, 14: 37-48.

Calantone, R. J., Cavusgil, S. T., \& Zhao, Y. 2002. Learning orientation, firm innovation capability, and firm performance. Industrial Marketing Management, 31: $515-524$.
Caliendo, M., Fossen, F. M., \& Kritikos, A. S. 2009. Risk attitudes of nascent entrepreneurs-New evidence from an experimentally validated survey. Small Business Economics, 32: 153-167.

Cannella, A., Jones, C., \& Withers, M. 2015. Family-versus lone-founder-controlled public corporations: Social identity theory and boards of directors. Academy of Management Journal, 58: 436-459.

Capon, N., Farley, J. U., \& Hoenig, S. 1990. Determinants of financial performance: A meta-analysis. Management Science, 36: 1143-1159.

Cardinal, L. B. 2001. Technological innovation in the pharmaceutical industry: The use of organizational control in managing research and development. Organization Science, 12: 19-36.

Carnes, C. M., \& Ireland, R. D. 2013. Familiness and innovation: Resource bundling as the missing link. Entrepreneurship Theory and Practice, 37: 13991419.

Carney, M. 2005. Corporate governance and competitive advantage in family-controlled firms. Entrepreneurship Theory and Practice, 29: 249-265.

Carney, M., Gedajlovic, E. R., Heugens, P. P., Van Essen, M., \& Van Oosterhout, J. H. 2011. Business group affiliation, performance, context, and strategy: A metaanalysis. Academy of Management Journal, 54: 437-460.

Chen, H.-L., \& Hsu, W.-T. 2009. Family ownership, board independence, and R\&D investment. Family Business Review, 22: 347-362.

Chesbrough, H. W. 1999. The organizational impact of technological change: A comparative theory of national institutional factors. Industrial and Corporate Change, 8: 447-485.

Chesbrough, H. W. 2003. Open innovation: The new imperative for creating and profiting from technology. Boston, MA: Harvard Business Press.

Cheung, M. W. L., \& Chan, W. 2005. Meta-analytic structural equation modeling: A two-stage approach. Psychological Methods, 10: 40-64.

Chrisman, J. J., Chua, J. H., \& Litz, R. A. 2004. Comparing the agency costs of family and non-family firms: Conceptual issues and exploratory evidence. Entrepreneurship Theory and Practice, 28: 335-354.

Chrisman, J. J., \& Patel, P. 2012. Variations in R\&D investments of family and non-family firms: Behavioral agency and myopic loss aversion perspectives. Academy of Management Journal, 55: 976-997.

Chua, J. H., Chrisman, J. J., \& Chang, E. P. 2004. Are family firms born or made? An exploratory investigation. Family Business Review, 17: 37-54. 
Chua, J. H., Chrisman, J. J., Steier, L. P., \& Rau, S. B. 2012. Sources of heterogeneity in family firms: An introduction. Entrepreneurship Theory and Practice, 36: 1103-1113.

Claessens, S., Djankov, S., Fan, J. P. H., \& Lang, L. H. P. 2002. Disentangling the incentive and entrenchment effects of large shareholdings. The Journal of Finance, 57: 2741-2771.

Cohen, J. 1960. A coefficient of agreement for nominal scales. Educational and Psychological Measurement, 20: 37-46.

Cohen, W. M., \& Levinthal, D. A. 1990. Absorptive capacity: A new perspective on learning and innovation. Administrative Science Quarterly, 35: 128-152.

Colombo, M. G., \& Grilli, L. 2005. Founders' human capital and the growth of new technology-based firms: A competence-based view. Research Policy, 34: 795-816.

Combs, J. G., Ketchen, D. J., Jr., Crook, T. R., \& Roth, P. L. 2011. Assessing cumulative evidence within "macro" research: Why meta-analysis should be preferred over vote counting. Journal of Management Studies, 48: 178-197.

Connelly, B. L., Tihanyi, L., Certo, S. T., \& Hitt, M. A. 2010. Marching to the beat of different drummers: The influence of institutional owners on competitive actions. Academy of Management Journal, 53: 723-742.

Cooper, R. G., \& Kleinschmidt, E. J. 1987. New products: What separates winners from losers? Journal of Product Innovation Management, 4: 169-184.

Croci, E., Doukas, J. A., \& Gonenc, H. 2011. Family control and financing decisions. European Financial Management, 17: 860-897.

Crossan, M. M., \& Apaydin, M. 2010. A multi-dimensional framework of organizational innovation: A systematic review of the literature. Journal of Management Studies, 47: 1154-1191.

Crossan, M. M., Lane, H. W., \& White, R. E. 1999. An organizational learning framework: From intuition to institution. Academy of Management Review, 24: 522-537.

Cruz, C. C., Gómez-Mejía, L. R., \& Becerra, M. 2010. Perceptions of benevolence and the design of agency contracts: CEO-TMT relationships in family firms. Academy of Management Journal, 53: 69-89.

Cucculelli, M., Le Breton-Miller, I., \& Miller, D. 2014. Product innovation, firm renewal and family governance, Firm Renewal and Family Governance (June 4). Available at SSRN: http://ssrn.com/abstract $=2446091$.

D’Aveni, R. A., Dagnino, G. B., \& Smith, K. G. 2010. The age of temporary advantage. Strategic Management Journal, 31: 1371-1385.
Dahlander, L., \& Gann, D. M. 2010. How open is innovation? Research Policy, 39: 699-709.

Dalton, D., Daily, C., Certo, S., \& Roengpitya, R. 2003. Metaanalyses of financial performance and equity: Fusion or confusion? Academy of Management Journal, 46: 13-26.

Damanpour, F. 1991. Organizational innovation: A metaanalysis of effects of determinants and moderators. Academy of Management Journal, 34: 555-590.

De Massis, A., Frattini, F., \& Lichtenthaler, U. 2013. Research on technological innovation in family firms: Present debates and future directions. Family Business Review, 26: 10-31.

Dess, G. G., \& Picken, J. C. 2000. Changing roles: Leadership in the 21st century. Organizational Dynamics, 28: 18-34.

Djankov, S., La Porta, R., Lopez-de-Silanes, F., \& Shleifer, A. 2008. The law and economics of self-dealing. Journal of Financial Economics, 88: 430-465.

Donnelley, R. G. 1964. The family business. Harvard Business Review, 42: 93-105.

Dosi, G. 1982. Technological paradigms and technological trajectories. Research Policy, 11: 147-162.

Dyck, A., \& Zingales, L. 2004. Private benefits of control: An international comparison. The Journal of Finance, 59: $537-600$

Economist. 2009. Dynastie and durability. Available at http://www.economist.com/node/14517406.

Eisenhardt, K. M., \& Martin, J. A. 2000. Dynamic capabilities: What are they? Strategic Management Journal, 21: 1105-1121.

European Commission. 2013. 2013 EU industrial R\&D investment scoreboard. Luxembourg: Publications Office of the European Union.

Fahlenbrach, R. 2009. Founder-CEOs, investment decisions, and stock market performance. Journal of Financial and Quantitative Analysis, 44: 439-466.

Fama, E. F., \& Jensen, M. C. 1983. Separation of ownership and control. The Journal of Law \& Economics, 26: 301-325.

Finkelstein, S., \& Hambrick, D. C. 1990. Top-managementteam tenure and organizational outcomes: The moderating role of managerial discretion. Administrative Science Quarterly, 35: 484-503.

Fiss, P. C., \& Zajac, E. J. 2004. The diffusion of ideas over contested terrain: The (non)adoption of a shareholder value orientation among German firms. Administrative Science Quarterly, 49: 501-534.

Furman, J. L., Porter, M. E., \& Stern, S. 2002. The determinants of national innovative capacity. Research Policy, 31: 899-933. 
Garud, R., \& Kumaraswamy, A. 1995. Technological and organizational designs for realizing economies of substitution. Strategic Management Journal, 16: 93-109.

Garud, R., Tuertscher, P., \& Van de Ven, A. H. 2013. Perspectives on innovation processes. The Academy of Management Annals, 7: 775-819.

Gassmann, O., Enkel, E., \& Chesbrough, H. 2010. The future of open innovation. R \& D Management, 40: 213-221.

Gedajlovic, E., \& Carney, M. 2010. Markets, hierarchies, and families: Toward a transaction cost theory of the family firm. Entrepreneurship Theory and Practice, 34: 1145-1172.

Gedajlovic, E., Lubatkin, M. H., \& Schulze, W. S. 2004. Crossing the threshold from founder management to professional management: A governance perspective. Journal of Management Studies, 41: 899-912.

Gerstner, W.-C., König, A., Enders, A., \& Hambrick, D. C. 2013. CEO narcissism, audience engagement, and organizational adoption of technological discontinuities. Administrative Science Quarterly, 58: 257-291.

Geyskens, I., Krishnan, R., Steenkamp, J.-B. E. M., \& Cunha, P. V. 2009. A review and evaluation of meta-analysis practices in management research. Journal of Management, 35: 393-419.

Geyskens, I., Steenkamp, J.-B. E., \& Kumar, N. 2006. Make, buy, or ally: A transaction cost theory meta-analysis. Academy of Management Journal, 49: 519-543.

Gilbert, C. G. 2005. Unbundling the structure of inertia: Resource versus routine rigidity. Academy of Management Journal, 48: 741-763.

Gimmon, E., \& Levie, J. 2010. Founder's human capital, external investment, and the survival of new high-technology ventures. Research Policy, 39: 1214-1226.

Gómez-Mejía, L. R., Campbell, J. T., Martin, G., Hoskisson, R. E., Makri, M., \& Sirmon, D. G. 2014. Socioemotional wealth as a mixed gamble: Revisiting family firm R\&D investments with the behavioral agency model. Entrepreneurship Theory and Practice, 38: 13511374.

Gómez-Mejía, L. R., Larraza-Kintana, M., \& Makri, M. 2003. The determinants of executive compensation in family-controlled public corporations. Academy of Management Journal, 46: 226-237.

Gómez-Mejía, L. R., Makri, M., \& Larraza-Kintana, M. 2010. Diversification decisions in family-controlled firms. Journal of Management Studies, 47: 223-252.

Gómez-Mejía, L. R., Núñez-Nickel, M., \& Gutierrez, I. 2001. The role of family ties in agency contracts. Academy of Management Journal, 44: 81-95.
Gómez-Mejía, L. R., Takács-Haynes, K., Núnez-Nickel, M., Jacobson, K. J. L., \& Moyano-Fuentes, J. 2007. Socioemotional wealth and business risks in familycontrolled firms: Evidence from Spanish olive oil mills. Administrative Science Quarterly, 52: 106-137.

Gordon, J. 2008. Shareholder initiative: A social choice and game theoretic approach to corporate law. University of Cincinnati Law Review, 60: 347-386.

Graham, J. R., Harvey, C. R., \& Rajgopal, S. 2005. The economic implications of corporate financial reporting. Journal of Accounting and Economics, 40: 3-73.

Greene, W. H. 2003. Econometric analysis. Upper Saddle River, NY: Prentice-Hall.

Greve, H. R. 2003. A behavioral theory of R\&D expenditures and innovations: Evidence from shipbuilding. Academy of Management Journal, 46: 685-702.

Gudmundson, D., Tower, C. B., \& Hartman, E. A. 2003. Innovation in small businesses: Culture and ownership structure do matter. Journal of Developmental Entrepreneurship, 8: 1-17.

Gulati, R. 1995. Does familiarity breed trust? The implications of repeated ties for contractual choice in alliances. Academy of Management Journal, 38: 85-112.

Habbershon, T. G., \& Williams, M. L. 1999. A resourcebased framework for assessing the strategic advantages of family firms. Family Business Review, 12: $1-25$.

Hadjimanolis, A. 2000. An investigation of innovation antecedents in small firms in the context of a small developing country. RED Management, 30: 235-246.

Hambrick, D. C., \& Mason, P. A. 1984. Upper echelons: The organization as a reflection of its top managers. Academy of Management Review, 9: 193-206.

Hedges, L., \& Olkin, I. 1985. Statistical methods for metaanalysis. Orlando, FL: Academic Press.

Henderson, R. M., \& Clark, K. B. 1990. Architectural innovation: The reconfiguration of existing product technologies and the failure of established firms. Administrative Science Quarterly, 35: 9-30.

Henderson, R. M., \& Cockburn, I. 1994. Measuring competence? Exploring firm effects in pharmaceutical research. Strategic Management Journal, 15(S1): 63-84.

Hendry, J., Sanderson, P., Barker, R., \& Roberts, J. 2006. Owners or traders? Conceptualizations of institutional investors and their relationship with corporate managers. Human Relations, 59: 1101-1132.

Heugens, P. P., \& Lander, M. W. 2009. Structure! Agency! (And other quarrels): A meta-analysis of institutional theories of organization. Academy of Management Journal, 52: 61-85. 
Heugens, P. P., Van Essen, M., \& Van Oosterhout, J. H. 2009. Meta-analyzing ownership concentration and firm performance in Asia: Towards a more fine-grained understanding. Asia Pacific Journal of Management, 26: 481-512.

Hitt, M. A., Hoskisson, R. E., Ireland, R. D., \& Harrison, J. S. 1991. Effects of acquisitions on R\&D inputs and outputs. Academy of Management Journal, 34: 693-706.

Holland, P. G., \& Oliver, J. E. 1992. An empirical examination of the stages of development of family business. Journal of Business and Entrepreneurship, 4: 27-38.

Hoskisson, R. E., Covin, J., Volberda, H. W., \& Johnson, R. A. 2011. Revitalizing entrepreneurship: The search for new research opportunities. Journal of Management Studies, 48: 1141-1168.

Hoskisson, R. E., Hitt, M. A., Johnson, R. A., \& Grossman, W. 2002. Conflicting voices: The effects of institutional ownership heterogeneity and internal governance on corporate innovation strategies. Academy of Management Journal, 45: 697-716.

Hsieh, T.-J., Yeh, R.-S., \& Chen, Y.-J. 2010. Business group characteristics and affiliated firm innovation: The case of Taiwan. Industrial Marketing Management, 39: $560-570$.

Hunter, J., \& Schmidt, F. 2004. Methods of meta-analysis: Correcting error and bias in research findings. Thousand Oaks, CA: Sage.

Jansen, J. J., Van Den Bosch, F. A., \& Volberda, H. W. 2005. Managing potential and realized absorptive capacity: How do organizational antecedents matter? Academy of Management Journal, 48: 999-1015.

Jansen, J. J., Vera, D., \& Crossan, M. 2009. Strategic leadership for exploration and exploitation: The moderating role of environmental dynamism. The Leadership Quarterly, 20: 5-18.

Jayaraman, N., Khorana, A., Nelling, E., \& Covin, J. 2000. CEO founder status and firm financial performance. Strategic Management Journal, 21: 1215-1224.

Jensen, M. C. 2002. Value maximization, stakeholder theory, and the corporate objective function. Business Ethics Quarterly, 12: 235-256.

Jung, D. I., Chow, C., \& Wu, A. 2003. The role of transformational leadership in enhancing organizational innovation: Hypotheses and some preliminary findings. The Leadership Quarterly, 14: 525-544.

Kammerlander, N., \& Ganter, M. 2015. An attention-based view of family firm adaptation to discontinuous technological change: Exploring the role of family CEOs' non-economic goals. Journal of Product Innovation Management, 32: 361-383.
Kanter, R. M. 1983. The change masters: Innovation and productivity in American corporations. New York, NY: Simon and Schuster.

Kaplan, S. N., Sensoy, B. A., \& Strömberg, P. 2009. Should investors bet on the jockey or the horse? Evidence from the evolution of firms from early business plans to public companies. The Journal of Finance, 64: 75-115.

Kemp, R. G. M., Folkeringa, M., De Jong, J. P. J., \& Wubben, E. F. M. 2003. Innovation and firm performance, Zoetermeer, Netherlands: EIM Business \& Policy Research.

Kepes, S., McDaniel, M. A., Brannick, M. T., \& Banks, G. C. 2013. Meta-analytic reviews in the organizational sciences: Two meta-analytic schools on the way to MARS (the Meta-Analytic Reporting Standards). Journal of Business and Psychology, 28: 123-143.

Kim, H., Kim, H., \& Lee, P. M. 2008. Ownership structure and the relationship between financial slack and R\&D investments: Evidence from Korean firms. Organization Science, 19: 404-418.

Kisamore, J. L., \& Brannick, M. T. 2008. An illustration of the consequences of meta-analysis model choice. Organizational Research Methods, 11: 35-53.

Klein, K. J., \& Sorra, J. S. 1996. The challenge of innovation implementation. Academy of Management Review, 21: 1055-1080.

Kline, S. J., \& Rosenberg, N. 1986. An overview of innovation. In R. Landau \& N. Rosenberg (Eds.), The positive sum strategy: Harnessing technology for economic growth, vol. 14: 275-305. Washington, DC: National Academy Press.

Klomp, J., \& De Haan, J. 2010. Inflation and central bank independence: A meta-regression analysis. Journal of Economic Surveys, 24: 593-621.

Klomp, L., \& Van Leeuwen, G. 2001. Linking innovation and firm performance: A new approach. International Journal of the Economics of Business, 8: 343-364.

Kochhar, R., \& David, P. 1996. Institutional investors and firm innovation: A test of competing hypotheses. Strategic Management Journal, 17: 73-84.

Kogut, B., \& Zander, U. 1992. Knowledge of the firm, combinative capabilities, and the replication of technology. Organization Science, 3: 383-397.

König, A., Kammerlander, N., \& Enders, A. 2013. The family innovator's dilemma: How family influence affects the adoption of discontinuous technologies by incumbent firms. Academy of Management Review, 38: 418-441.

Kotlar, J., \& De Massis, A. 2013. Goal setting in family firms: Goal diversity, social interactions, and collective commitment to family-centered goals. Entrepreneurship Theory and Practice, 37: 1263-1288. 
Kotlar, J., De Massis, A., Frattini, F., Fang, H., \& Bianchi, M. 2013. Technology acquisition in family and nonfamily firms: A longitudinal analysis of Spanish manufacturing firms. Journal of Product Innovation Management, 30: 1073-1085.

Landis, R. S. 2013. Successfully combining meta-analysis and structural equation modeling: Recommendations and strategies. Journal of Business and Psychology, 28: 251-261.

Lansberg, I. 1999. Succeeding generations. Boston, MA: Harvard Business School Press.

La Porta, R., Lopez-de-Silanes, F., \& Shleifer, A. 1999. Corporate ownership around the world. The Journal of Finance, 54: 471-517.

La Porta, R., Lopez-de-Silanes, F., Shleifer, A., \& Vishny, R. W. 1998. Law and finance. Journal of Political Economy, 106: 1113-1155.

Laursen, K., Masciarelli, F., \& Prencipe, A. 2012. Trapped or spurred by the home region? The effects of potential social capital on involvement in foreign markets for goods and technology. Journal of International Business Studies, 43: 783-807.

Lazonick, W., \& O’Sullivan, M. 2000. Maximizing shareholder value: A new ideology for corporate governance. Economy and Society, 29: 13-35.

Le Breton-Miller, I., \& Miller, D. 2008. To grow or to harvest? Governance, strategy and performance in family and lone founder firms. Journal of Strategy and Management, 1: 41-56.

Le Breton-Miller, I., \& Miller, D. 2015. Learning stewardship in family firms: For family, by family across the life cycle. Academy of Management Learning $\mathcal{\sigma}$ Education, 14: 386-399.

Leonard-Barton, D. 1992. Core capabilities and core rigidities: A paradox in managing new product development. Strategic Management Journal, 13: 111-125.

Lester, R. H., \& Cannella, A. A. 2006. Interorganizational familiness: How family firms use interlocking directorates to build community-level social capital. Entrepreneurship Theory and Practice, 30: 755-775.

Levitt, B., \& March, J. 1988. Organizational learning. Annual Review of Sociology, 14: 319-340.

Lipsey, M., \& Wilson, D. 2001. Practical meta-analysis. Thousands Oaks, CA: Sage.

Llach, J., \& Nordqvist, M. 2010. Innovation in family and non-family businesses: A resource perspective. International Journal of Entrepreneurial Venturing, 2: 381-399.

Lundvall, B.- $\AA$. 2010. National systems of innovation: Toward a theory of innovation and interactive learning. London, UK: Anthem Press.
Madhavan, R., \& Grover, R. 1998. From embedded knowledge to embodied knowledge: New product development as knowledge management. Journal of Marketing, 62: 1-12.

McClelland, D. C. 1965. Achievement and entrepreneurship: A longitudinal study. Journal of Personality and Social Psychology, 1: 389-392.

McGrath, R. G. 1997. A real options logic for initiating technology positioning investments. Academy of Management Review, 22: 974-996.

Miller, D., \& Le Breton-Miller, I. 2005. Managing for the long run. Boston, MA: Harvard Business School Press.

Miller, D., Le Breton-Miller, I., \& Lester, R. H. 2011. Family and lone founder ownership and strategic behaviour: Social context, identity, and institutional logics. Journal of Management Studies, 48: 1-25.

Miller, D., Le Breton-Miller, I., \& Lester, R. H. 2013. Family firm governance, strategic conformity, and performance: Institutional vs. strategic perspectives. Organization Science, 24: 189-209.

Miller, D., Le Breton-Miller, I., Lester, R. H., \& Cannella, A. A., Jr. 2007. Are family firms really superior performers? Journal of Corporate Finance, 13: 829-858.

Miller, D., Le Breton-Miller, I., Minichilli, A., Corbetta, G., \& Pittino, D. 2014. When do non-family CEOs outperform in family firms? Agency and behavioural agency perspectives. Journal of Management Studies, 51: 547-572.

Miller, K. D., \& Folta, T. B. 2002. Option value and entry timing. Strategic Management Journal, 23: 655-665.

Mishra, C. S., \& McConaughy, D. L. 1999. Founding family control and capital structure: The risk of loss of control and the aversion of debt. Entrepreneurship Theory and Practice, 23: 53-64.

Morck, R., \& Yeung, B. 2003. Agency problems in large family business groups. Entrepreneurship Theory and Practice, 27: 367-382.

Mudambi, R., \& Swift, T. 2011. Proactive R\&D management and firm growth: A punctuated equilibrium model. Research Policy, 40: 429-440.

Mumford, M. D., \& Licuanan, B. 2004. Leading for innovation: Conclusions, issues, and directions. The Leadership Quarterly, 15: 163-171.

Munari, F., Oriani, R., \& Sobrero, M. 2010. The effects of owner identity and external governance systems on R\&D investments: A study of Western European firms. Research Policy, 39: 1093-1104.

Naldi, L., Cennamo, C., Corbetta, G., \& Gómez-Mejía, L. 2013. Preserving socioemotional wealth in family firms: Asset or liability? The moderating role of 
business context. Entrepreneurship Theory and Practice, 37: 1341-1360.

Nelson, R. R. 1993. National innovation systems: A comparative analysis. New York, NY: Oxford University Press.

Nelson, T. 2003. The persistence of founder influence: Management, ownership, and performance effects at initial public offering. Strategic Management Journal, 24: 707-724.

Nieß, C., \& Biemann, T. 2014. The role of risk propensity in predicting self-employment. The Journal of Applied Psychology, 99: 1000-1009.

Nohria, N., \& Gulati, R. 1996. Is slack good or bad for innovation? Academy of Management Journal, 39: 1245-1264.

Nonaka, I., \& Takeuchi, H. 1995. The knowledge-creating company: How Japanese companies create the dynamics of innovation. Oxford, UK: Oxford University Press.

O’Boyle, E. H., Jr., Pollack, J. M., \& Rutherford, M. W. 2012. Exploring the relation between family involvement and firms' financial performance: A meta-analysis of main and moderator effects. Journal of Business Venturing, 27: 1-18.

Pakes, A., \& Griliches, Z. 1980. Patents and R\&D at the firm level: A first report. Economics Letters, 5: 377-381.

Patel, P. C., \& Chrisman, J. J. 2014. Risk abatement as a strategy for R\&D investments in family firms. Strategic Management Journal, 35: 617-627.

Pearson, A. W., Carr, J. C., \& Shaw, J. C. 2008. Toward a theory of familiness: A social capital perspective. Entrepreneurship Theory and Practice, 32: 949-969.

Peng, M. W., \& Jiang, Y. 2010. Institutions behind family ownership and control in large firms. Journal of Management Studies, 47: 253-273.

Peng, M. W., Sun, L. S., Pinkham, B., \& Chen, H. 2009. The institution-based view as a third leg for a strategy tripod. The Academy of Management Perspectives, 23: 63-81.

Peng, M. W., Wang, D. Y., \& Jiang, Y. 2008. An institutionbased view of international business strategy: A focus on emerging economies. Journal of International Business Studies, 39: 920-936.

Pennings, J. M., \& Harianto, F. 1992. The diffusion of technological innovation in the commercial banking industry. Strategic Management Journal, 13: 29-46.

Phelps, C. C. 2010. A longitudinal study of the influence of alliance network structure and composition on firm exploratory innovation. Academy of Management Journal, 53: 890-913.
Pierce, J. L., \& Delbecq, A. L. 1977. Organization structure, individual attitudes and innovation. Academy of Management Review, 2: 27-37.

Piezunka, H., \& Dahlander, L. 2015. Distant search, narrow attention: How crowding alters organizations' filtering of suggestions in crowdsourcing. Academy of Management Journal, 58: 856-880.

Pinto, J. K., \& Prescott, J. E. 1988. Variations in critical success factors over the stages in the project life cycle. Journal of Management, 14: 5-18.

Polanyi, M. 1973. Personal knowledge. London, UK: Routledge \& Kegan Paul.

Post, C., \& Byron, K. 2015. Women on boards and firm financial performance: A meta-analysis. Academy of Management Journal, 58: 1546-1571.

Raudenbush, S., \& Bryk, A. 2002. Hierarchical linear models: Applications and data analysis methods. Thousand Oaks, CA: Sage.

Roberts, E. B., \& Fusfeld, A. R. 1981. Staffing the innovative technology-based organization. Sloan Management Review, 22: 19-34.

Rosenbusch, N., Brinckmann, J., \& Bausch, A. 2011. Is innovation always beneficial? A meta-analysis of the relationship between innovation and performance in SMEs. Journal of Business Venturing, 26: 441-457.

Rosenthal, R. 1979. The file drawer problem and tolerance for null results. Psychological Bulletin, 86: 638-641.

Rosenthal, R. 1991. Meta-analysis: a review. Psychosomatic Medicine, 53: 247-271.

Rosing, K., Frese, M., \& Bausch, A. 2011. Explaining the heterogeneity of the leadership-innovation relationship: Ambidextrous leadership. The Leadership Quarterly, 22: 956-974.

Rost, K. 2011. The strength of strong ties in the creation of innovation. Research Policy, 40: 588-604.

Rothaermel, F. T., \& Hess, A. M. 2007. Building dynamic capabilities: Innovation driven by individual-, firm-, and network-level effects. Organization Science, 18: 898-921.

Schmid, T., Achleitner, A.-K., Ampenberger, M., \& Kaserer, C. 2014. Family firms and R\&D behavior-New evidence from a large-scale survey. Research Policy, 43: 233-244.

Schmiedeberg, C. 2008. Complementarities of innovation activities: An empirical analysis of the German manufacturing sector. Research Policy, 37: 14921503.

Schreier, M., \& Prügl, R. 2008. Extending lead-user theory: Antecedents and consequences of consumers' lead userness. Journal of Product Innovation Management, 25: 331-346. 
Schumpeter, J. A. 1934. The theory of economic development. Cambridge, MA: Harvard University Press.

Sciascia, S., \& Mazzola, P. 2008. Family involvement in ownership and management: Exploring nonlinear effects on performance. Family Business Review, 21: 331-345.

Scott, W. R. 2001. Institutions and organizations. Thousand Oaks, CA: Sage.

Shane, S., Venkataraman, S., \& MacMillan, I. 1995. Cultural differences in innovation championing strategies. Journal of Management, 21: 931-952.

Sharma, P., Chrisman, J. J., \& Gersick, K. E. 2012. 25 years of Family Business Review: Reflections on the past and perspectives for the future. Family Business Review, 25: 5-15.

Shleifer, A. 1998. State versus private ownership, Working Paper. National Bureau of Economic Research.

Simester, D., \& Zhang, J. 2010. Why are bad products so hard to kill? Management Science, 56: 11611179.

Simon, H. 1996. Hidden champions: Lessons from 500 of the world's best unknown companies. Cambridge, MA: Harvard Business Press.

Simons, R. 1995. Levers of control. Boston, MA: Harvard University Press.

Singla, C., Veliyath, R., \& George, R. 2013. Family firms and internationalization-governance relationships: Evidence of secondary agency issues. Strategic Management Journal, 35: 606-616.

Sirmon, D. G., Arregle, J. L., Hitt, M. A., \& Webb, J. W. 2008. The role of family influence in firms' strategic responses to threat of imitation. Entrepreneurship Theory and Practice, 32: 979-998.

Sirmon, D. G., \& Hitt, M. A. 2003. Managing resources: Linking unique resources, management, and wealth creation in family firms. Entrepreneurship Theory and Practice, 27: 339-358.

Sirmon, D. G., Hitt, M. A., \& Ireland, R. D. 2007. Managing firm resources in dynamic environments to create value: Looking inside the black box. Academy of Management Review, 32: 273-292.

Sirmon, D. G., Hitt, M. A., Ireland, R. D., \& Gilbert, B. A. 2011. Resource orchestration to create competitive advantage breadth, depth, and life cycle effects. Journal of Management, 37: 1390-1412.

Spamann, H. 2010. The "antidirector rights index" revisited. Review of Financial Studies, 23: 467-486.

Stanley, T., \& Doucouliagos, H. 2012. Meta-regression analysis in economics and business. New York, NY: Routledge.
Stanley, T. D., Doucouliagos, H., Giles, M., Heckemeyer, J. H., Johnston, R. J., Laroche, P., Nelson, J. P., Paldam, M., Poot, J., Pugh, G., Rosenberger, R. S., \& Rost, K. 2013. Meta-analysis of ecomomics research reporting guidelines. Journal of Economic Surveys, 27: 390-394.

Stewart, A., \& Hitt, M. A. 2012. Why can't a family business be more like a nonfamily business? Modes of professionalization in family firms. Family Business Review, 25: 58-86.

Subramaniam, M., \& Youndt, M. A. 2005. The influence of intellectual capital on the types of innovative capabilities. Academy of Management Journal, 48: $450-463$.

Sydow, J., Schreyögg, G., \& Koch, J. 2009. Organizational path dependence: Opening the black box. Academy of Management Review, 34: 689-709.

Tan, W.-L., \& Fock, S. T. 2001. Coping with growth transitions: The case of Chinese family businesses in Singapore. Family Business Review, 14: 123-139.

Teece, D. J., Pisano, G., \& Shuen, A. 1997. Dynamic capabilities and strategic management. Strategic Management Journal, 18: 509-533.

Thomke, S. H. 2003. Experimentation matters: Unlocking the potential of new technologies for innovation. Boston, MA: Harvard Business Press.

Thomsen, S., \& Pedersen, T. 1996. Nationality and ownership structures: The 100 largest companies in six European nations. Management International Review, 36: 149-166.

Tsao, S., \& Lien, W. 2013. Family management and internationalization: The impact of firm performance and innovation. Management International Review, 27: $390-394$.

Tushman, M. L., \& O’Reilly, C. A. 1996. Ambidextrous organizations: Managing evolutionary and revolutionary change. California Management Review, 36: 8-30.

Tyre, M. J., \& Von Hippel, E. 1997. The situated nature of adaptive learning in organizations. Organization Science, 8: 71-83.

Uhlaner, L. M. 2013. Family business and corporate governance. In M. Wright, D. S. Siegel, K. Keasey, \& I. Filatotchev (Eds.), Oxford handbook of corporate governance: 389-420. Oxford, UK: Oxford University Press.

Uzzi, B. 1997. Social structure and competition in interfirm networks: The paradox of embeddedness. Administrative Science Quarterly, 42: 35-67.

Vaccaro, I. G., Jansen, J. J., Van Den Bosch, F. A., \& Volberda, H. W. 2012. Management innovation and leadership: The moderating role of organizational size. Journal of Management Studies, 49: 28-51. 
Van Essen, M., Heugens, P. P., Otten, J., \& Van Oosterhout, J. H. 2012. An institution-based view of executive compensation: A multilevel meta-analytic test. Journal of International Business Studies, 43: 396-423.

Van Essen, M., Otten, J., \& Carberry, E. J. 2015. Assessing managerial power theory: A meta-analytic approach to understanding the determinants of CEO compensation. Journal of Management, 41: 164-202.

Varsakelis, N. C. 2006. Education, political institutions and innovative activity: A cross-country empirical investigation. Research Policy, 35: 1083-1090.

Verona, G. 1999. A resource-based view of product development. Academy of Management Review, 24: 132-142.

Villalonga, B., \& Amit, R. 2006. How do family ownership, control and management affect firm value? Journal of Financial Economics, 80: 385-417.

Villalonga, B., \& Amit, R. 2009. How are US family firms controlled? Review of Financial Studies, 22: 30473091.

Viswesvaran, C., \& Ones, D. S. 1995. Theory testing: Combining psychometric meta-analysis and structural equations modeling. Personnel Psychology, 48: 865-885.

Von Hippel, E. 2005. Democratizing innovation. Cambridge, MA: MIT press.

Von Hippel, E., Franke, N., \& Prügl, R. 2009. Pyramiding: Efficient search for rare subjects. Research Policy, 38: 1397-1406.

Von Krogh, G., Ichijo, K., \& Nonaka, I. 2000. Enabling knowledge creation: How to unlock the mystery of tacit knowledge and release the power of innovation. Oxford, UK: Oxford University Press.

Wagner, D., Block, J. H., Miller, D., Schwens, C., \& Xi, G. 2015. A meta-analysis of the financial performance of family firms: Another attempt. Journal of Family Business Strategy, 6: 3-13.

Wasserman, N. 2003. Founder-CEO succession and the paradox of entrepreneurial success. Organization Science, 14: 149-172.

West, M. A., Borrill, C. S., Dawson, J. F., Brodbeck, F., Shapiro, D. A., \& Haward, B. 2003. Leadership clarity and team innovation in health care. The Leadership Quarterly, 14: 393-410.

White, H. 1994. Scientific communication and literature retrieval. New York, NY: Russell Sage Foundation.

Wiseman, R. M., \& Gómez-Mejía, L. R. 1998. A behavioral agency model of managerial risk taking. Academy of Management Review, 23: 133-153.

$\mathrm{Wu}$, H.-L. 2008. When does internal governance make firms innovative? Journal of Business Research, 61: 141-153.
Wu, S., Levitas, E., \& Priem, R. L. 2005. CEO tenure and company invention under differing levels of technological dynamism. Academy of Management Journal, 48: 859-873.

Yayavaram, S., \& Chen, W. R. 2015. Changes in firm knowledge couplings and firm innovation performance: The moderating role of technological complexity. Strategic Management Journal, 36: 377-396.

Zahra, S. A. 2003. International expansion of US manufacturing family businesses: The effect of ownership and involvement. Journal of Business Venturing, 18: 495-512.

Zahra, S. A., \& George, G. 2002. Absorptive capacity: A review, reconceptualization, and extension. Academy of Management Review, 27: 185-203.

Zellweger, T. M. 2007. Time horizon, costs of equity capital, and generic investment strategies of firms. Family Business Review, 20: 1-15.

Zellweger, T. M., Eddleston, K. A., \& Kellermanns, F. W. 2010. Exploring the concept of familiness: Introducing family firm identity. Journal of Family Business Strategy, 1: 54-63.

Zellweger, T. M., Kellermanns, F. W., Chrisman, J. J., \& Chua, J. H. 2012. Family control and family firm valuations by family CEOs: The importance of intentions for transgenerational control. Organization Science, 23: 851-868.

Zhang, A., Zhang, Y., \& Zhao, R. 2003. A study of the R\&D efficiency and productivity of Chinese firms. Journal of Comparative Economics, 31: 444-464.

Zingales, L. 2000. In search of new foundations. The Journal of Finance, 55: 1623-1653.

Zollo, M., \& Winter, S. G. 2002. Deliberate learning and the evolution of dynamic capabilities. Organization Science, 13: 339-351.

\section{M}

Patricio Duran (patricio.duran@uai.cl) is an assistant professor of management and strategy at the Universidad Adolfo Ibáñez, Chile. He received his $\mathrm{PhD}$ in business administration, with a concentration in international business, from the University of South Carolina. His research interests include comparative corporate governance, global strategy, and institutions.

Nadine Kammerlander (nadine.kammerlander@whu.edu) holds the family business chair at WHU-Otto Beisheim School of Management in Vallendar, Germany. She received her $\mathrm{PhD}$ from the Otto-Friedrich-University Bamberg, Germany. Her research interests include innovation and technology, governance, and family businesses. 
Marc van Essen (marc.vanessen@unisg.ch) is professor of entrepreneurship and innovation in the School of Management at the University of St. Gallen. He received his PhD from the Rotterdam School of Management, Erasmus University. His research interests include comparative corporate governance, family business, and global strategy.
Thomas Zellweger (thomas.zellweger@unisg.ch) holds the family business chair at the University of St. Gallen, where he also received his $\mathrm{PhD}$. His research mainly deals with strategic management, entrepreneurship, and governance of family-controlled companies.

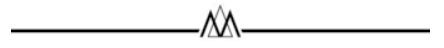




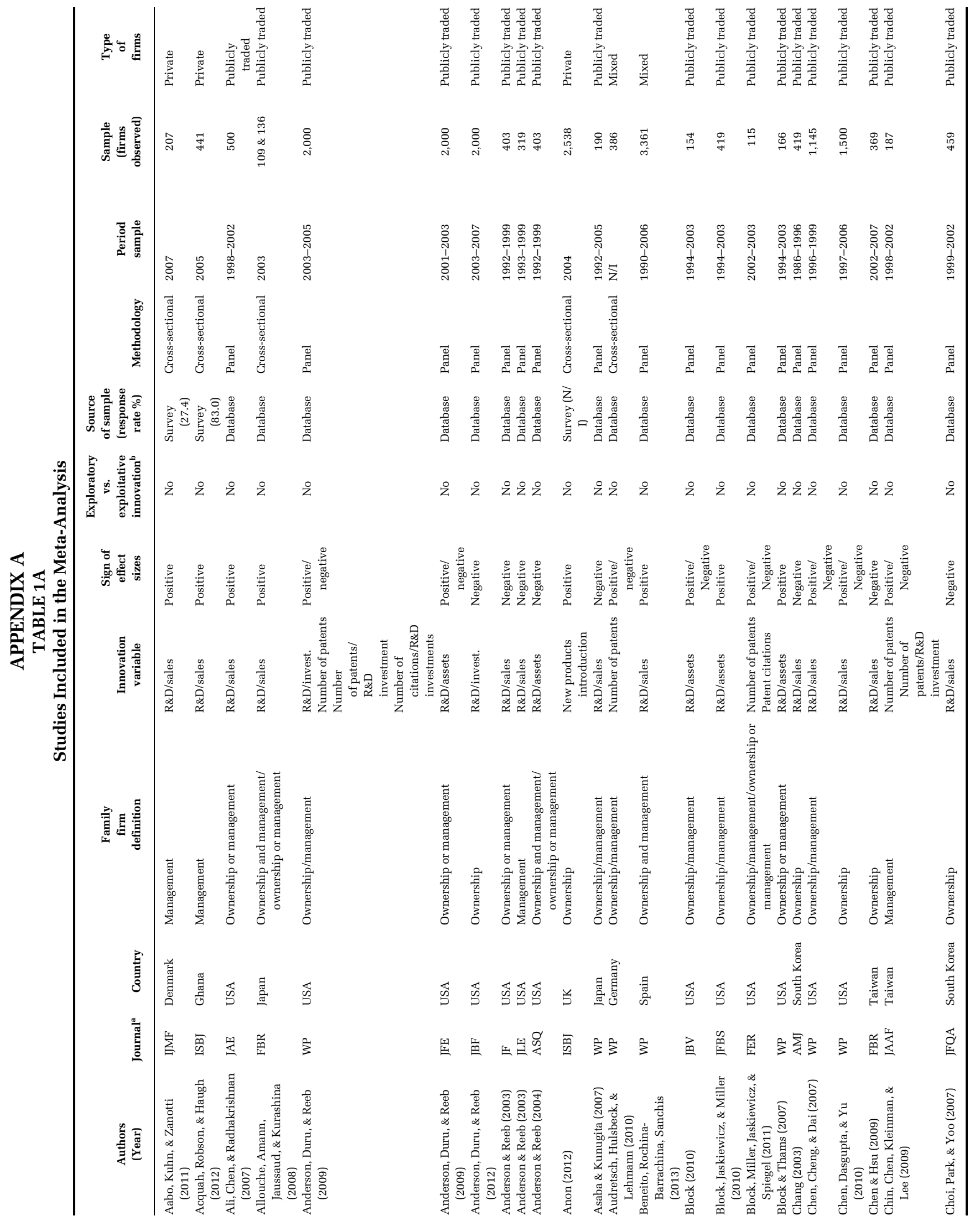




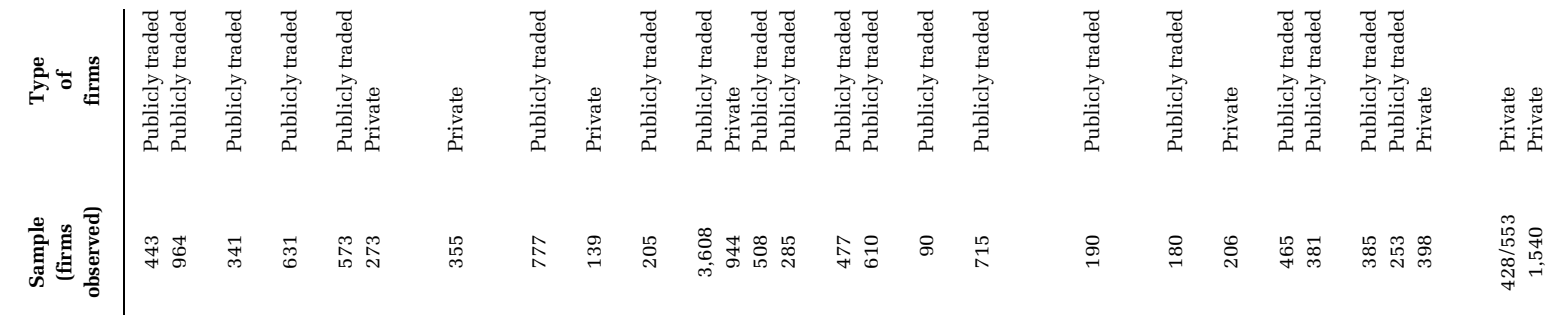

苨莣

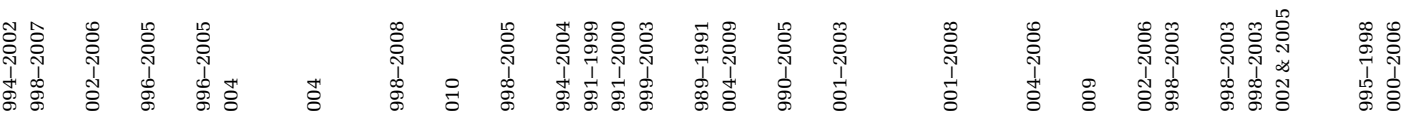

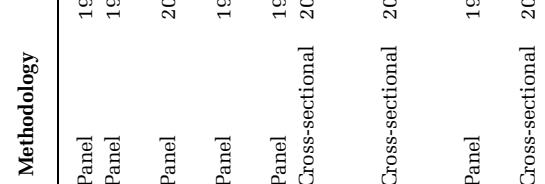

H

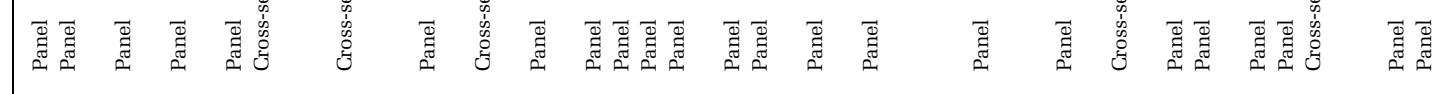

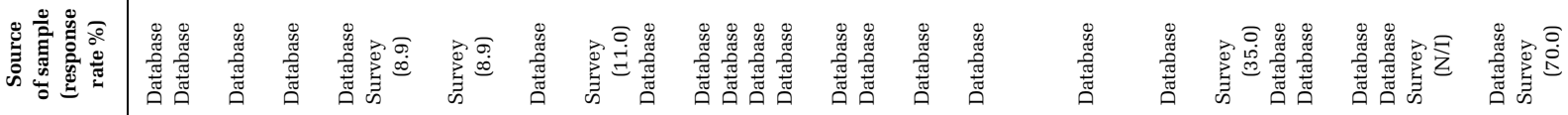

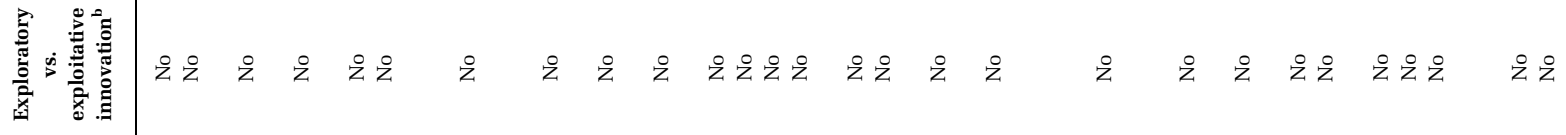

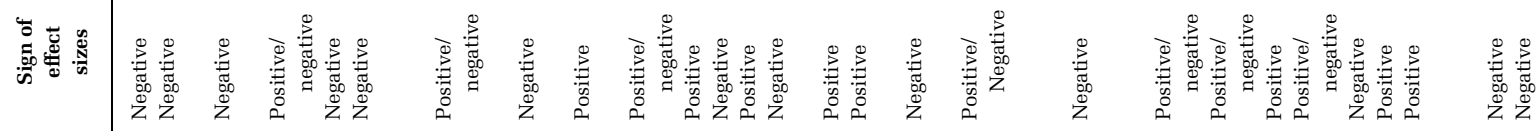

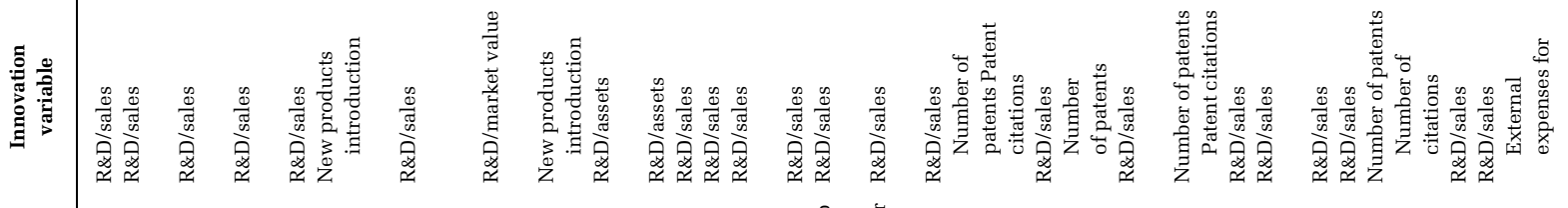

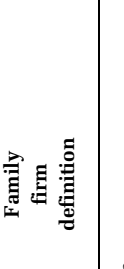

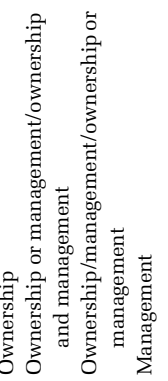

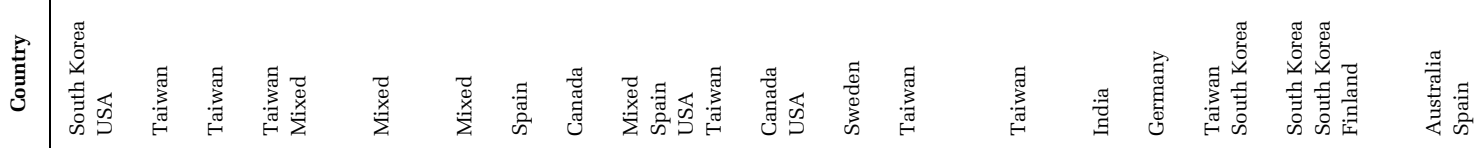

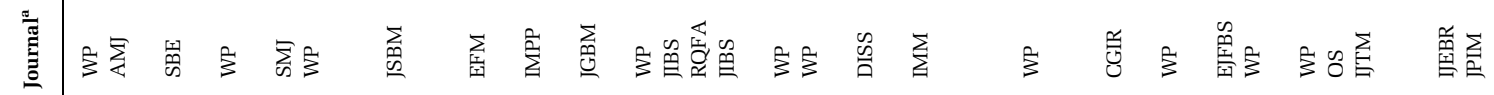

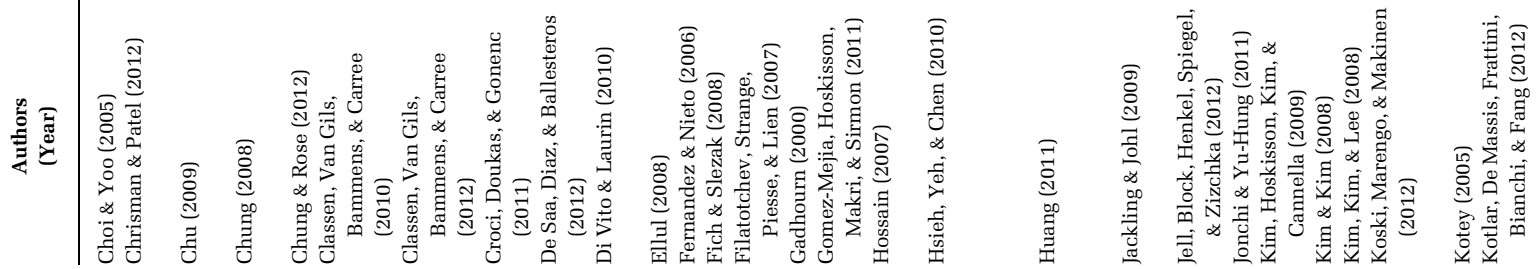




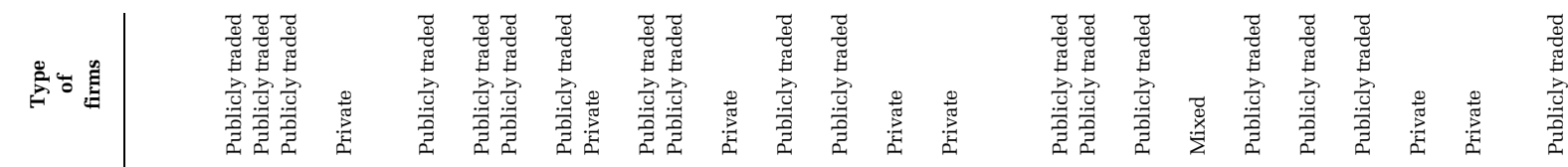

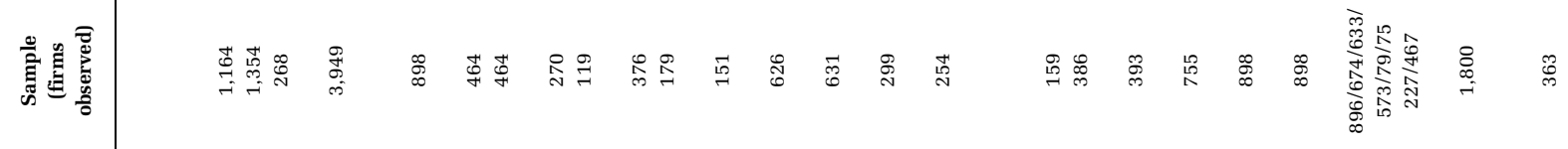

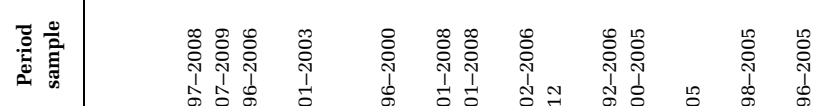

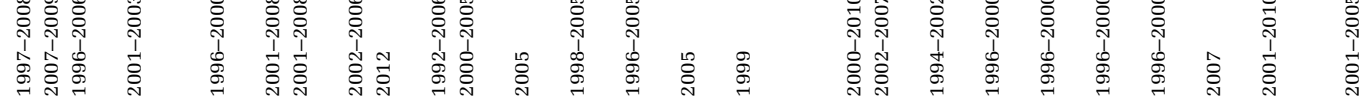

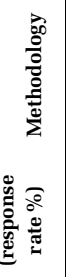

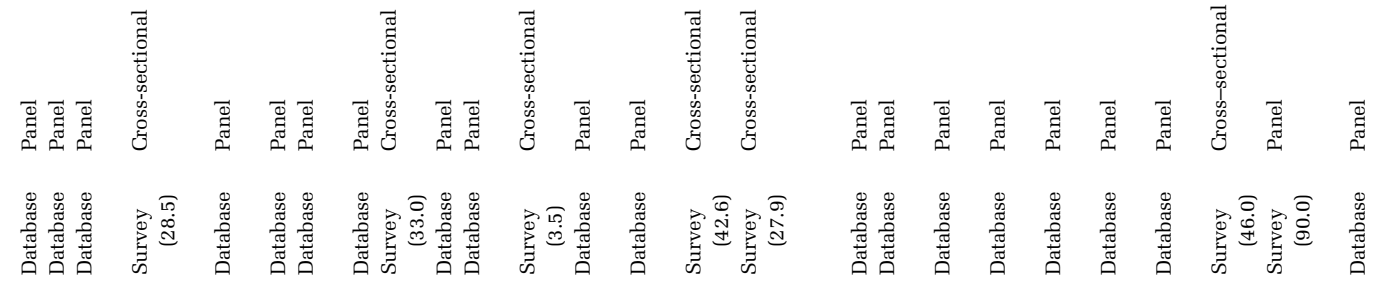

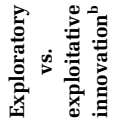

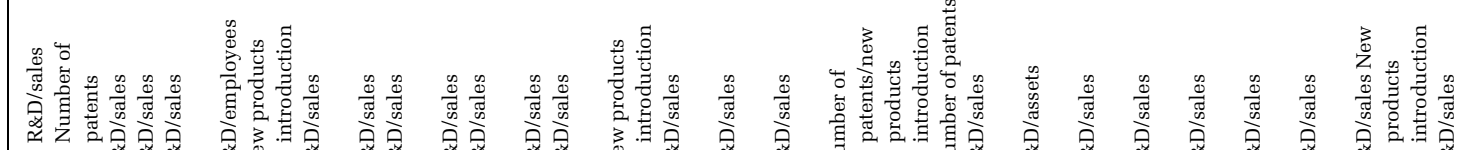

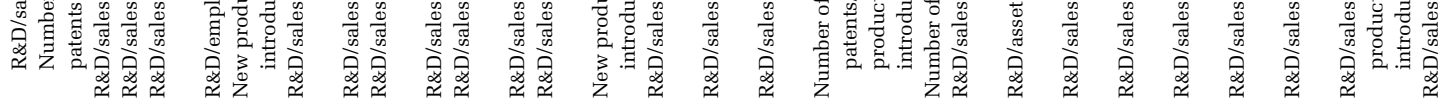

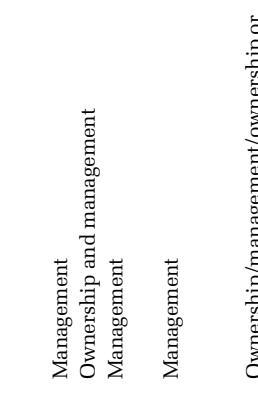
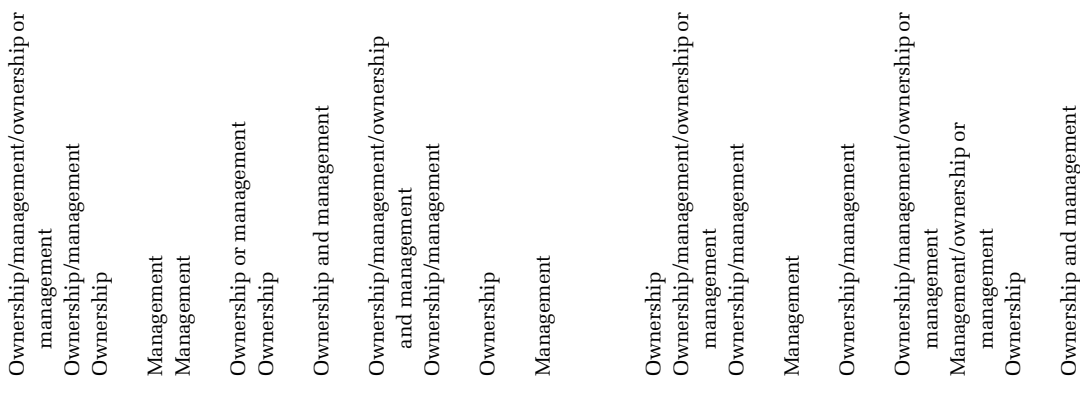

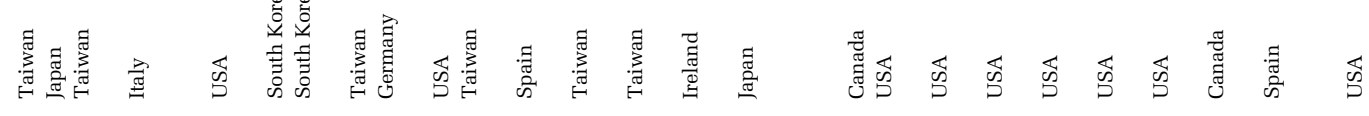

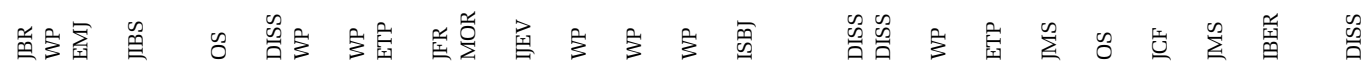

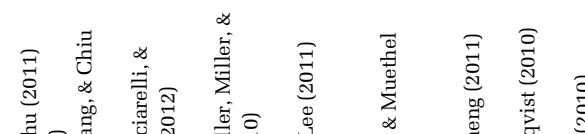

总焉 矛

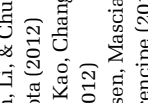

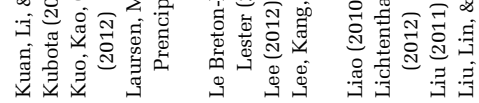




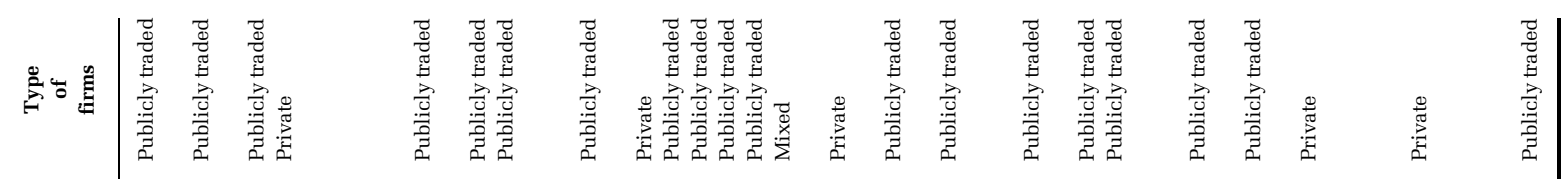

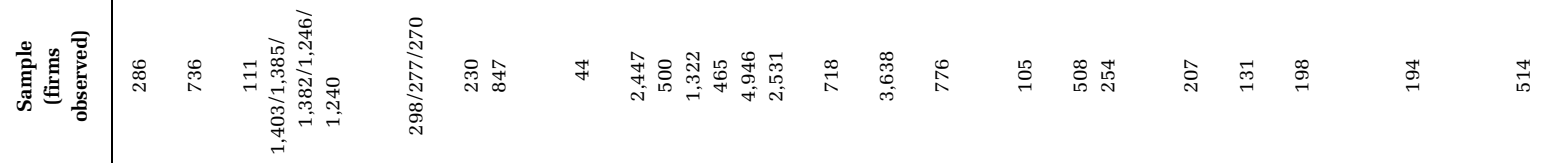

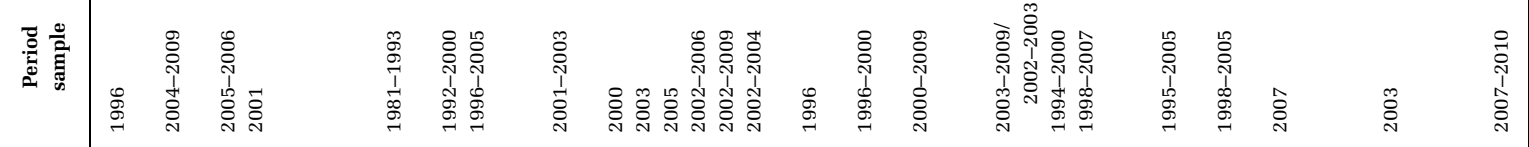

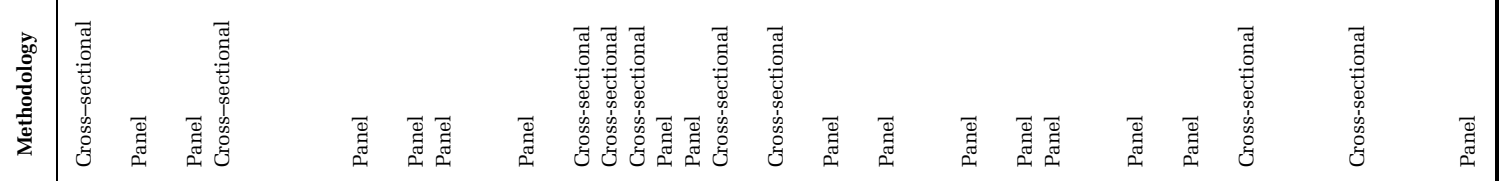

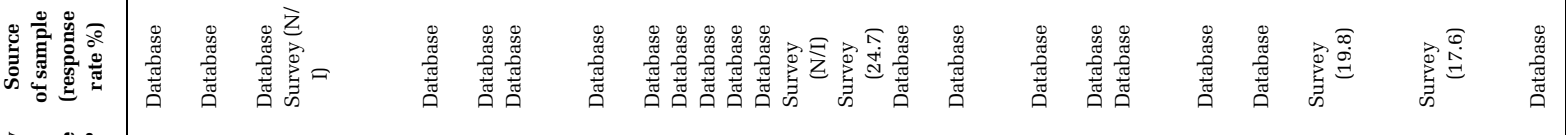

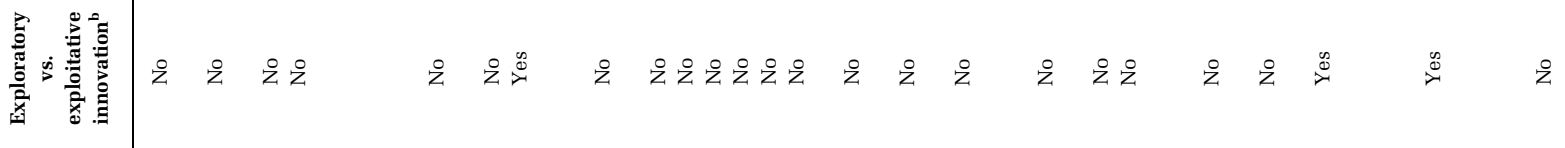

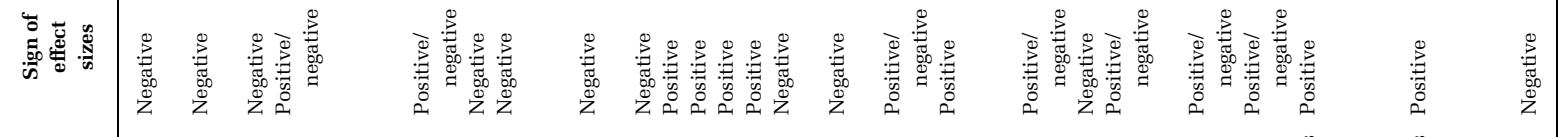

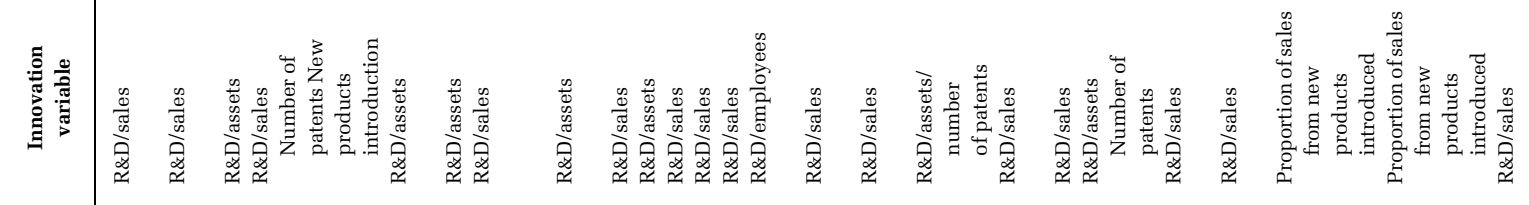

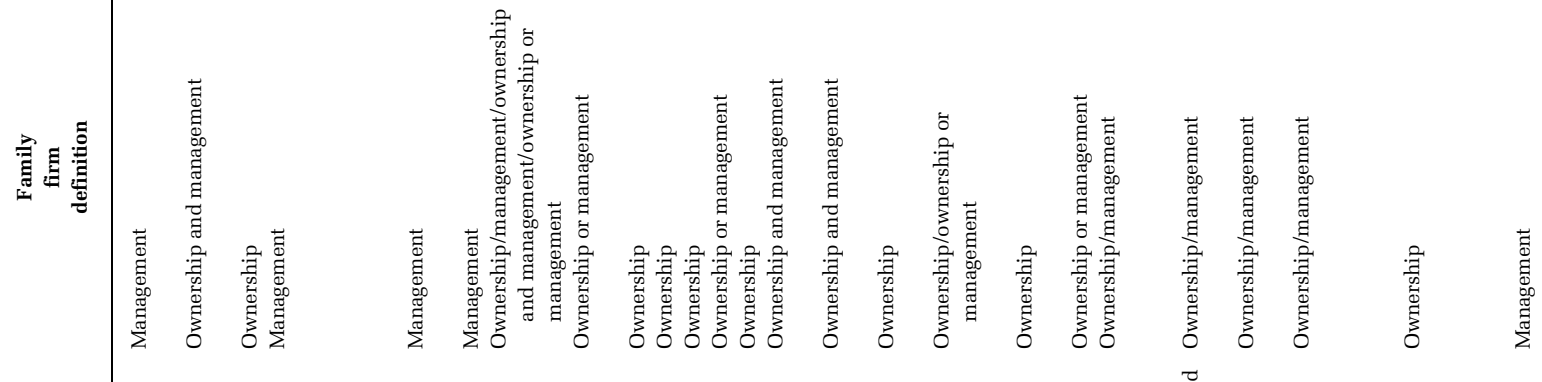

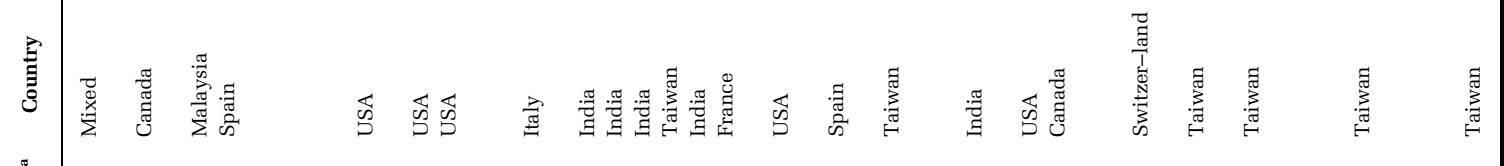

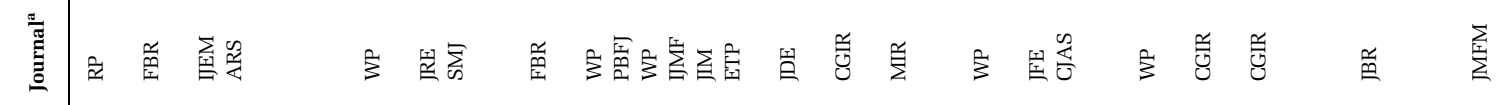

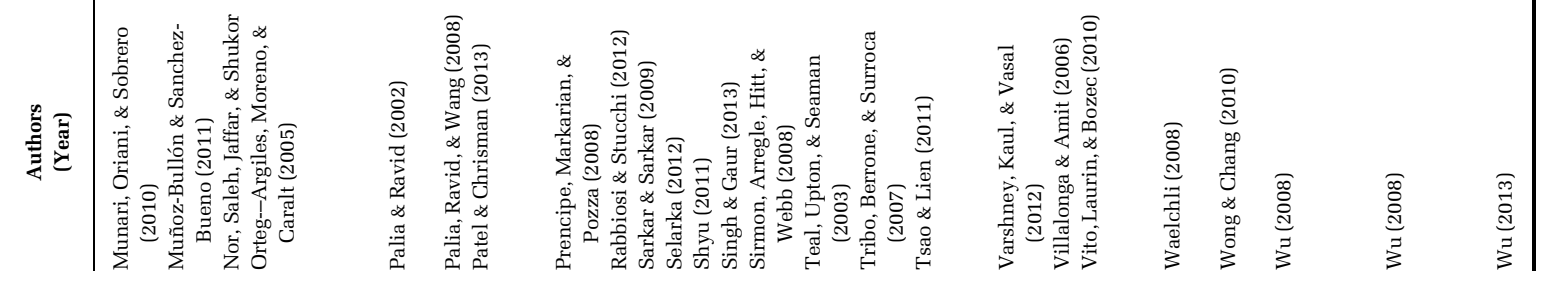




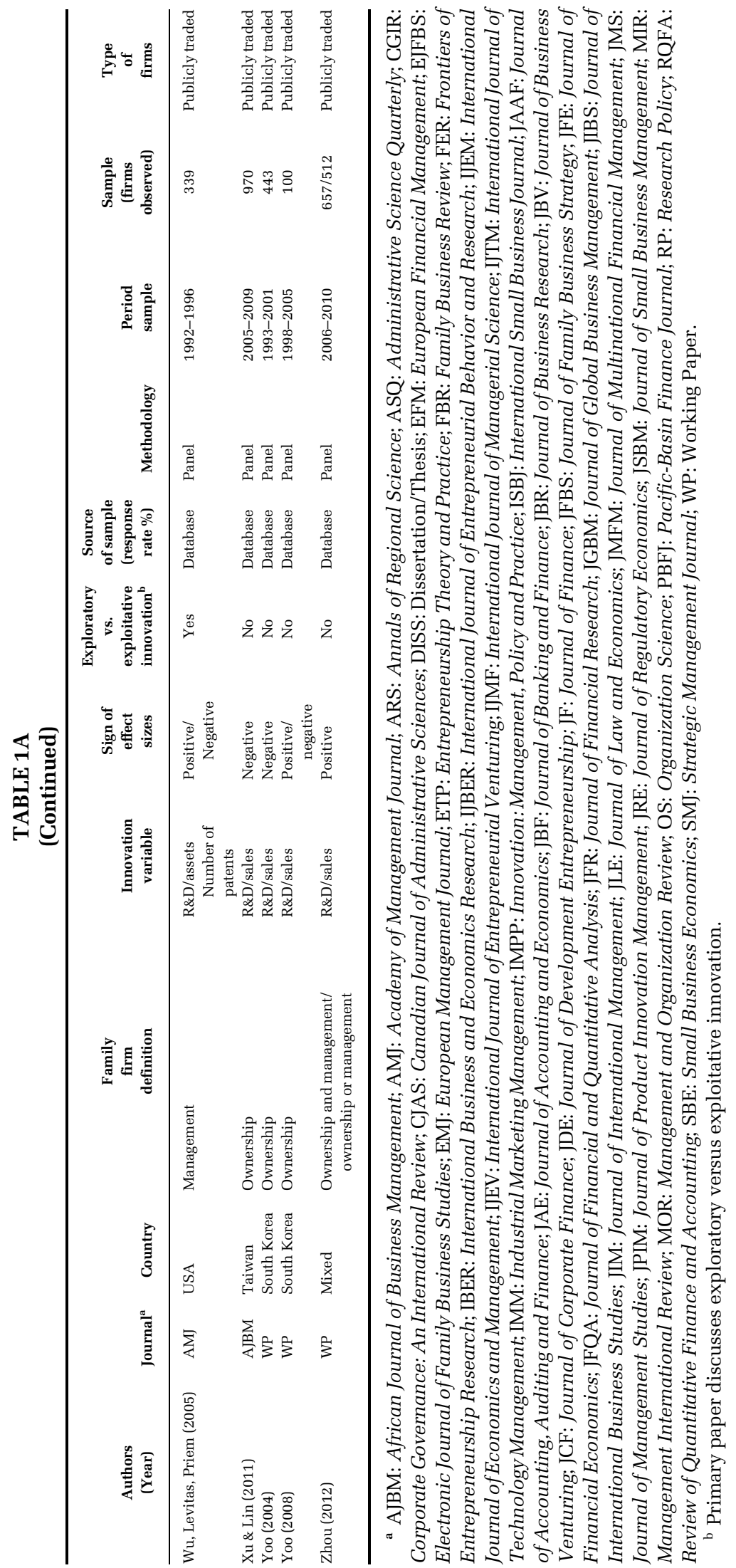




\section{APPENDIX B1 \\ TABLE B1 \\ HOMA Results}

\begin{tabular}{|c|c|c|c|c|c|c|c|}
\hline Predictor & $\boldsymbol{k}$ & \multicolumn{6}{|c|}{ Pearson product-moment correlation ( $r$ ) } \\
\hline Ownership & 79 & 52,030 & $-0.05 *$ & 0.01 & $-0.07 /-0.03$ & $330.92(0.00)$ & 0.76 \\
\hline Management & 86 & 51,049 & -0.01 & 0.01 & $-0.03 / 0.02$ & $707.18(0.00)$ & 0.88 \\
\hline Family role in firms: & & & & & & & \\
\hline Family CEO & 27 & 15,261 & -0.04 & 0.02 & $-0.09 / 0.01$ & $231.27(0.00)$ & 0.89 \\
\hline Founder CEO & 31 & 14,196 & $\mathbf{0 . 0 6}^{+}$ & 0.03 & $-0.00 / 0.11$ & $342.89(0.00)$ & 0.91 \\
\hline Other family management role ${ }^{\mathrm{b}}$ & 28 & 21,592 & $-0.04^{*}$ & 0.01 & $-0.07 /-0.01$ & $111.25(0.00)$ & 0.76 \\
\hline Family ownership & 79 & 52,030 & $-0.05^{*}$ & 0.01 & $-0.07 /-0.03$ & $330.92(0.00)$ & 0.76 \\
\hline $\begin{array}{l}\text { Other ownership or management role } \\
\text { Firm type: }\end{array}$ & 49 & 32,088 & $-0.03^{*}$ & 0.01 & $-0.06 /-0.01$ & $210.16(0.00)$ & 0.77 \\
\hline
\end{tabular}

Notes: $k=$ number of effect sizes; $n=$ firm observations; $S E=$ the standard error of the mean correlation; CI 95\% $=95$ percent confidence interval around the meta-analytic mean; $Q$ test = Hedges and Olkin (1985) $\chi^{2}$ test for homogeneity; and $I^{2}=$ scale-free index of heterogeneity.

${ }^{a}$ Innovation input variables include (1) R\&D/sales, (2) R\&D/assets, (3) R\&D/total investment, (4) employees focused on R\&D/total employees, (5) external expenses for R\&D/sales, and (6) R\&D/firm's market value of equity.

${ }^{\mathrm{b}}$ Other family role variables include family involvement in board of directors of the firm, professional CEO, and mixed management role. ${ }^{*} p<.05$

${ }^{+} p<.10$. 


\section{APPENDIX B2 \\ TABLE B2 \\ HOMA Results}

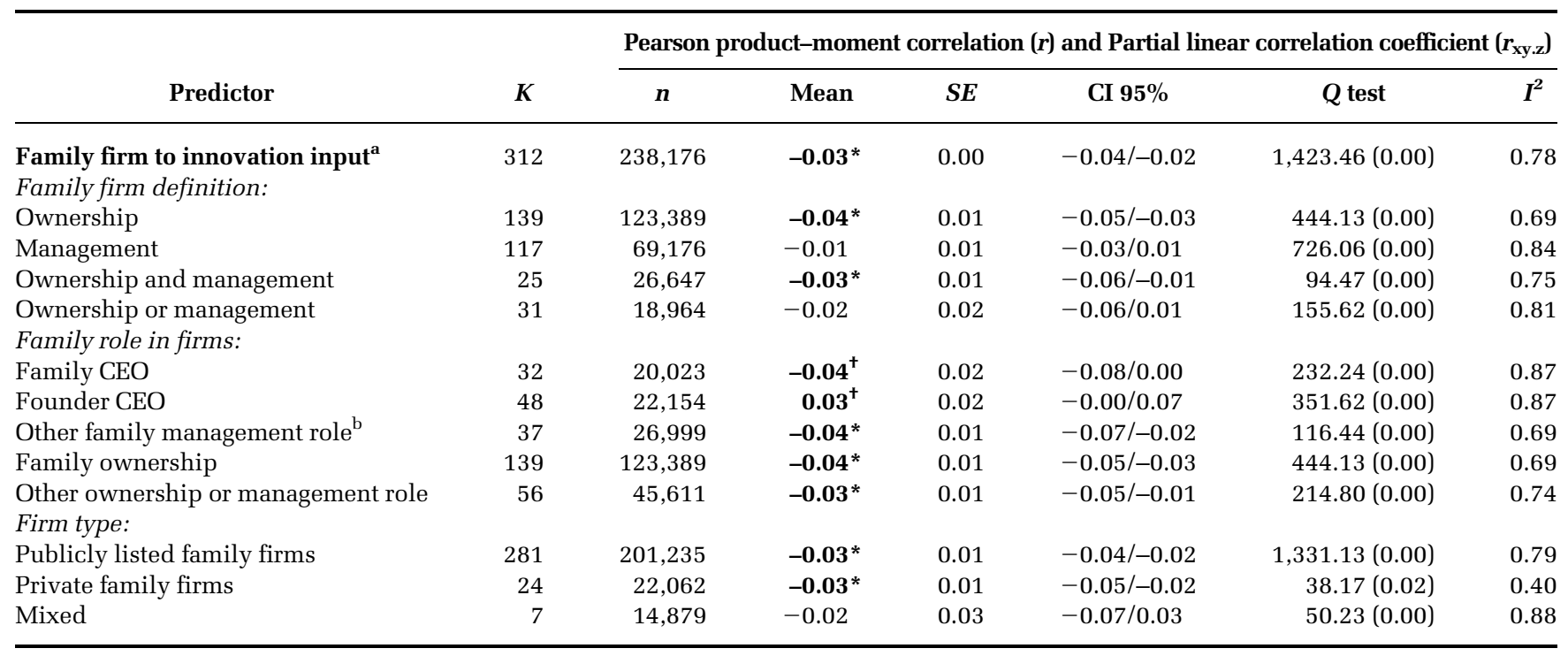

Notes: $k=$ number of effect sizes; $n=$ firm observations; $S E=$ the standard error of the mean correlation; CI 95\% $=95$ percent confidence interval around the meta-analytic mean; $Q$ test = Hedges and Olkin (1985) $\chi^{2}$ test for homogeneity; and $I^{2}=$ scale-free index of heterogeneity.

a Innovation input variables include (1) R\&D/sales, (2) R\&D/assets, (3) R\&D/total investment, (4) employees focused on R\&D/total employees, (5) external expenses for R\&D/sales, and (6) R\&D/Firm's market value of equity.

${ }^{\mathrm{b}}$ Other family role variables include family involvement in board of directors of the firm, professional CEO, and mixed management role. ${ }^{*} p<.05$

${ }^{+} p<.10$. 


\section{APPENDIX C1 \\ TABLE C1 \\ HOMA Results}

\begin{tabular}{|c|c|c|c|c|c|c|c|}
\hline Predictor & $K$ & \multicolumn{6}{|c|}{ Pearson product-moment correlation (r) } \\
\hline Ownership & 15 & 3,722 & 0.04 & 0.02 & $-0.01 / 0.08$ & $24.17(0.04)$ & 0.42 \\
\hline Management & 14 & 9,932 & -0.01 & 0.02 & $-0.06 / 0.04$ & $53.66(0.00)$ & 0.76 \\
\hline Family CEO & 4 & 2,399 & $0.07 *$ & 0.03 & $0.01 / 0.13$ & $6.48(0.09)$ & 0.54 \\
\hline Founder CEO & 5 & 1,211 & $-0.10^{+}$ & 0.05 & $-0.20 / 0.01$ & $13.61(0.01)$ & 0.71 \\
\hline Other family management role ${ }^{\mathrm{b}}$ & 5 & 6,322 & -0.01 & 0.02 & $-0.05 / 0.04$ & $8.45(0.08)$ & 0.53 \\
\hline Family ownership & 15 & 3,722 & 0.04 & 0.02 & $-0.01 / 0.08$ & $24.17(0.04)$ & 0.42 \\
\hline $\begin{array}{l}\text { Other ownership or management role } \\
\text { Firm type: }\end{array}$ & 8 & 3,769 & -0.01 & 0.04 & $-0.09 / 0.07$ & $34.20(0.00)$ & 0.80 \\
\hline
\end{tabular}

Notes: $k=$ number of effect sizes; $n=$ firm observations; $S E=$ the standard error of the mean correlation; CI 95\% $=95$ percent confidence interval around the meta-analytic mean; $Q$ test $=$ Hedges and Olkin (1985) $\chi^{2}$ test for homogeneity; and $I^{2}=$ scale-free index of heterogeneity.

a Innovation output variables include (1) number of patents, (2) number of patents/R\&D investment, (3) patent citations, (4) patent citations/ R\&D investment, (5) percentage of sales consisted on new products/services introduced, and (6) innovation introduction.

${ }^{\mathrm{b}}$ Other family role variables include family involvement in board of directors of the firm, professional CEO, and mixed management role.

${ }^{*} p<.05$

${ }^{+} p<.10$. 


\section{APPENDIX C2 \\ TABLE C2 \\ HOMA Results}

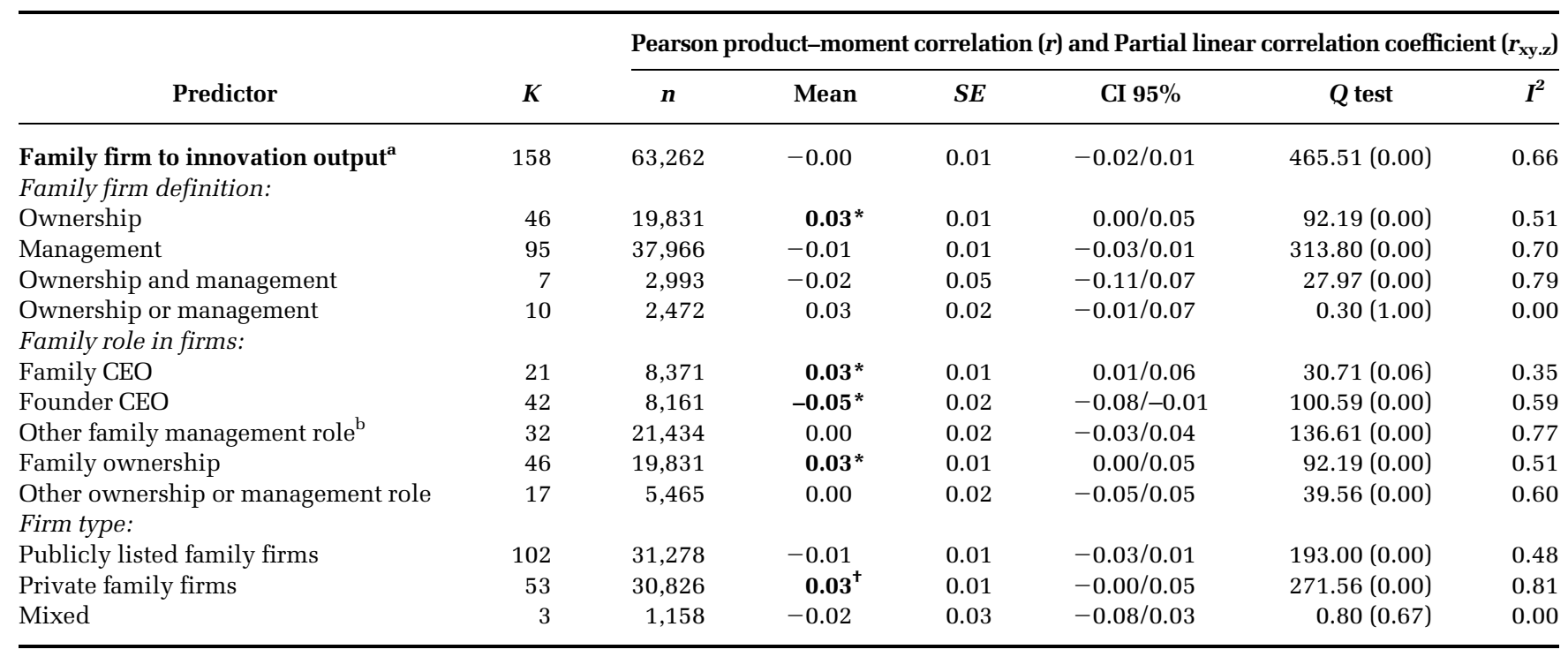

Notes: $k=$ number of effect sizes; $n=$ firm observations; $S E=$ the standard error of the mean correlation; CI 95\% $=95$ percent confidence interval around the meta-analytic mean; $Q$ test = Hedges and Olkin (1985) $\chi^{2}$ test for homogeneity; and $I^{2}=$ scale-free index of heterogeneity.

a Innovation output variables include (1) number of patents, (2) number of patents/R\&D investment, (3) patent citations, (4) patent citations/ R\&D investment, (5) percentage of sales consisted on new products/services introduced, and (6) innovation introduction.

${ }^{\mathrm{b}}$ Other family role variables include family involvement in board of directors of the firm, professional CEO, and mixed management role.

${ }^{*} p<.05$

${ }^{+} p<.10$. 